\title{
Recruitment of Baltic cod and sprat stocks: identification of critical life stages and incorporation of environmental variability into stock-recruitment relationships*
}

\author{
FRIEDRICH W. KÖSTER ${ }^{1,2}$, HANS-HARALD HINRICHSEN ${ }^{1}$, DIETRICH SCHNACK ${ }^{1}$, \\ MIKE A. ST. JOHN ${ }^{3}$, BRIAN R. MACKENZIE ${ }^{2}$, JONNA TOMKIEWICZ ${ }^{1,2}$, \\ CHRISTIAN MÖLLMANN ${ }^{1}$, GERD KRAUS ${ }^{1}$, MARIS PLIKSHS ${ }^{4}$, \\ ANDREJ MAKARCHOUK ${ }^{4}$ and EERO ARO ${ }^{5}$ \\ ${ }^{1}$ Institute of Marine Sciences, Düsternbrooker Weg 20, 24105 Kiel, Germany. E-mail: fkoester@ifm.uni-kiel.de \\ ${ }^{2}$ Danish Institute for Fisheries Research, Charlottenlund Castle, 2920 Charlottenlund, Denmark. \\ ${ }^{3}$ Institute of Hydrobiologie and Fisheries Science, Olbersweg 24, 22767 Hamburg, Germany. \\ ${ }^{4}$ Latvian Fisheries Research Institute, Daugavgrivas Street 8, 1007 Riga, Latvia. \\ ${ }^{5}$ Finnish Game and Fisheries Research Institute, P.O. Box 33. 00931 Helsinki, Finland.
}

\begin{abstract}
SUMMARY: The recruitment processes of Baltic cod and sprat were analysed and critical periods were identified by addressing the major impact factors on individual early life history stages separately and relating observed abundance data between successive stages. For cod, recruitment appeared to be dependent on egg survival, with low oxygen concentration in dwelling depths and predation by clupeids as the major causes for egg mortality. Surviving egg production and larval abundance were weakly correlated, whereas larval abundance was significantly related to year class strength. This indicated that the period between the late egg and the early larval stage is critical for cod recruitment. A potential variable identified to affect this life stage was prey availability for larvae. For sprat, early and late egg stage production as well as late egg stage production and larval abundance were significantly related. However, year class strength was largely independent of larval abundance. Thus, the period between the late larval and early juvenile stage appeared to be critical for sprat recruitment. Potential variables identified to affect this life stage were ambient temperature and wind stress. Environmental factors showing statistically significant covariance with the survival of one of these critical life stages were incorporated into stock-recruitment models for individual spawning areas separately and for the Central Baltic combined.
\end{abstract}

Key words: cod, sprat, Baltic, critical life stage, environment, stock-recruitment relationship.

\section{INTRODUCTION}

\section{General approach and stock development}

The present consensus in fisheries research is that the success of a year class is determined primarily by a series of density independent stochastic

\footnotetext{
*Received December 6, 2000. Accepted April 9, 2002.
}

processes acting on the egg, larval and early juvenile stages. These processes, such as co-occurrence with sub-optimal habitats, overlap with predators, reduce the abundance surviving to the juvenile stage. After this period of high mortality, subsequent survival success and recruitment to the fishery is primarily the result of density dependent processes such as competition for optimal habitat and cannibalism (e.g. Myers and Cadigan, 1993; Leggett and 
Deblois, 1994; Heath and Gallego, 1997). Superimposed on these external conditions, parental contributions to the quality (e.g. Trippel et al., 1997; Marteinsdottir and Steinarrson, 1998), quantity (Trippel, 1998; Lambert and Dutil, 2000) and spatio-temporal distribution of reproductive products (e.g. Hutchings and Myers, 1993; Begg and Marteinsdottir, 2000) affect the susceptibility of individuals to environmental conditions and determine the environmental conditions offspring are exposed to (St. John et al., 2000; Vallin and Nissling, 2000). In the present study we examine the reproductive success in two fish species, cod and sprat, characterised by differing life history strategies in a biologically simple but hydrographically complex system, the Central Baltic Sea. The analyses follows the success of a year-class during ontogeny from spawner abundance through the egg and larval to the juvenile stage according to Paulik's (1973) framework, thus considering various endogenous and external processes affecting reproductive success.

During the last two decades, a shift has occurred in the upper trophic level of the Central Baltic Sea Ecosystem, leading from a cod-dominated to a sprat-dominated system. The cod stock declined, due to recruitment failure and high fishing intensity (Bagge et al., 1994). The corresponding decrease in predation pressure on sprat, combined with low fishing mortality and high reproductive success for this species, resulted in a pronounced increase of the sprat stock (Parmanne et al., 1994). Apart from being the major prey species of cod in pre-spawning and spawning periods (Bagge et al., 1994), sprat has been identified as an important predator on cod eggs (Köster and Schnack, 1994). This type of biological interaction may stabilise the dominance of either cod or sprat in the system (Rudstam et al., 1994). A destabilisation of the system or shift in the species dominance may be caused by unfavourable hydrographic conditions for reproduction and subsequent recruitment failure of one of the species, and/or by a high species selective fishing mortality (Schnack, 1997). Cod and sprat utilise the same deep Baltic basins as spawning areas (Fig. 1), though sprat spawning is more distributed and less restricted to the deep parts of the basins. Also, the spawning times are largely overlapping (Bagge et al., 1994; Parmanne et al., 1994). Nevertheless, there is a pronounced difference in reproductive success of the two species, indicating a difference in the environmental requirements.
In the past 10-15 years a substantial effort has been made to examine the major processes assumed to affect the recruitment success of Eastern Baltic cod (Bagge and Thurow,1994; MacKenzie et al., 1996). The most recent activities are addressing also sprat, in order to adequately consider the strong interactions evidenced between the two species (Köster and Möllmann, 2000a; Köster et al., 2001a). As a result, several new data series of potential relevance for these processes have become available. We utilised this material to address the question whether standard assessment procedures provide estimates of spawning stock biomass, which can be used as a reliable measure of egg production. This has recently been questioned for a number of fish stocks (MacKenzie et al., 1998; Marshall et al., 1998; Marteinsdottir and Thorarinsson, 1998). The present paper presents results for Baltic cod and sprat, and summarises the information available or required to improve the stock-recruitment relationships for these two populations. Additionally, in order to disentangle processes acting on early pelagic and later demersal juveniles (Ulltang, 1996), the feasibility of estimating recruitment success before juveniles recruit to the fisheries was tested by comparing estimates derived from Multispecies Virtual Population Analysis (MSVPA) with abundance indices from research surveys.

The second task follows Paulik's (1973) approach, examining the entire life history process for critical periods and relationships between successive life stages (Rothschild, 1986). To our knowledge, only a few attempts have been made to follow this approach (e.g. Pacific salmon: Larkin and Hourston, 1964; walleye pollock in Shelikof Strait: Kendall et al., 1996; North Sea plaice: Beverton and Iles, 1992). A large amount of multi-disciplinary information is required and in almost all cases, including the Baltic, the major problems are lack of time series data on key processes and the variety and complexity of processes involved.

The third task aims at incorporation of environmental processes and species interaction into stockrecruitment relationships, as suggested by Sparholt (1996) and Jarre-Teichmann et al. (2000) for Baltic cod and by Grauman and Yula (1989) for sprat. Based on exploratory statistical analysis, variables were identified which showed significant covariance with survival rates during critical life stages. These variables were incorporated as impact factors into stock-recruitment models, which were established first for individual ICES Sub-divisions (i.e. spawn- 


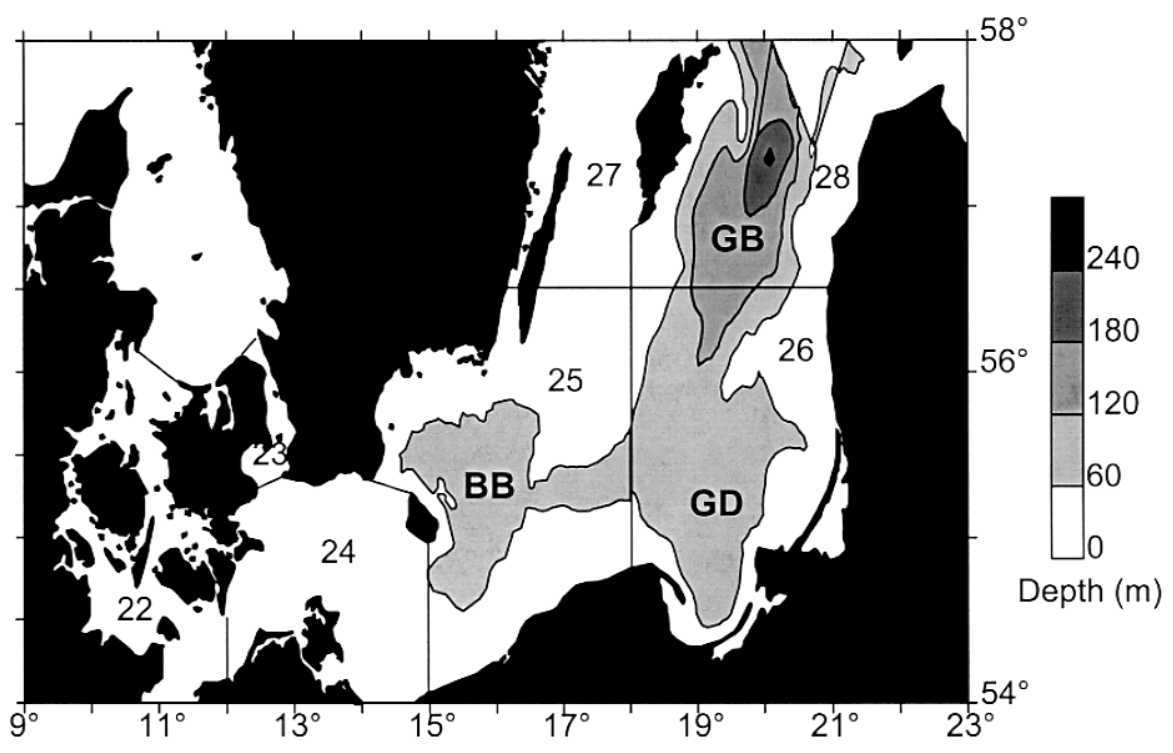

FIG. 1. - Major spawning areas of cod and sprat in the Central Baltic (BB: Bornholm Basin; GD: Gdansk Deep; GB: Gotland Basin; numbers: ICES Sub-divisions).

ing areas, Fig. 1), characterised by distinct hydrographic regimes (Plikshs et al., 1993; MacKenzie et $a l ., 2000)$ and differences in recruitment success and stock development (Ojaveer, 1989; Sparholt and Tomkiewicz, 2000). These area-specific models were then combined for the entire Central Baltic.

The Sub-division specific stock-recruitment relationships were established on the basis of area disaggregated Multispecies Virtual Population Analysis (Köster et al., 2001a). For cod, a first approach was presented by Köster et al. (2001b), in which mechanisms leading to area specific differences were identified. The present approach is an extension of the previous one, addressing the above mentioned aspects and extending the exploratory analysis to data on mesozooplankton abundance as a measure of prey availability for the larvae. For sprat, the present analysis is a new approach to explain differences among areas and establish environmentally sensitive recruitment models, specifically testing hypotheses on the significance of environmental factors suggested earlier (e.g. Grauman and Yula, 1989; Kalejs and Ojaveer, 1989; Raid, 1989).

\section{Environmental factors considered to be critical for year class success}

Due to low salinity in upper water layers of the Central Baltic, cod eggs do not float in surface waters, but concentrate in a narrow depth range within and below the permanent halocline (Wieland and Jarre-Teichmann, 1997). At this depth the eggs are frequently exposed to low oxygen concentration, and survival is largely reduced in these situations (Nissling, 1994; Wieland et al., 1994). Plikshs et al. (1993) defined a "reproductive volume" (RV) as an index for potential egg survival, i.e. the volume of water fulfilling minimum requirements for successful egg development. However, as this index does not consider the actual oxygen conditions inside the reproductive volume and the possibility that eggs may float outside the RV, two modifications of this index were employed in the present study.

Sprat eggs have on average a higher buoyancy than cod eggs (e.g. Wieland and Zuzarte, 1991) and by floating in higher ranges of the water column they are less affected by oxygen depletion in the deep water. However, they are sensitive to low temperatures (e.g. Thompson et al., 1981) and may be affected when floating in the cold water layer between the thermo- and the halocline formed in the Central Baltic during winter (Krenkel, 1981; Herra, 1988). Additionally, there is evidence that spawning activity and individual fecundity are affected by unfavourable temperature conditions in pre-spawning periods (Elwertowski, 1960; Petrowa, 1960). According to Grauman (1965), sprat egg survival in summer depends also on the wind conditions, with high wind stress resulting in a high mortality of eggs distributed during these months in upper water layers. Wind conditions also impact encounter rates of larvae and their prey as well as feeding success.

Jarre-Teichmann et al. (2000) demonstrated that the cumulative wind energy at peak spawning time 
affects cod recruitment. The suggested process is a transport of larvae and pelagic juveniles to coastal nursery habitats during periods of high wind stress and a retention in the central basins during periods of low wind stress of variable wind direction (Hinrichsen et al., 2001). Köster et al. (2001b) incorporated these transport processes in their exploratory analysis on cod recruitment processes by modifying the wind energy index to consider explicitly the direction of transport (larval transport index).

For sprat larvae preliminary hydrodynamic modelling approaches demonstrated the sensitivity of results from ichthyoplankton surveys to high wind stress, which may lead to a rapid advection of larvae out of the survey area (STORE, 2001). This rapid transport is caused by a concentration of sprat larvae in the upper-most water layers after successful completion of their initial vertical migration from the hatching depth. Grauman (1976) also described a large-scale wind-driven transport of sprat larvae from Sub-division 25 to 26 and 28 (Fig. 1).

Consumption of cod eggs by sprat has a significant impact on cod egg survival in the Bornholm Basin in spring and early summer, while later in the spawning season herring replaces sprat as a principal predator of cod eggs (Köster and Möllmann, 2000a). Similarly, egg cannibalism by sprat in the Bornholm Basin is a potential compensatory process limiting the reproductive success of the sprat stock (Köster and Möllmann, 2000b). Predation on cod eggs by sprat decreased throughout the 1990s while the importance of herring predation increased, due to a delay in spawning of cod (Wieland et al., 2000). Apart from intra- and inter-annual trends, there is also a spatial variation apparent in the intensity of egg predation which is considerably lower in the Gdansk Deep and Gotland Basin than in the Bornholm Basin. Existing data on sprat and herring diet composition suggest that the ratio of cod eggs in the stomachs and in the food supply is linearly related to the degree of overlap in their vertical distribution. The oxygen concentration in the bottom water limits the vertical distribution of clupeids during the daylight-feeding period, while the density regime determines the vertical distribution of cod eggs (Köster and Möllmann, 2000a). This observation led to the development of an index of vertical predator/prey overlap and enabled the prediction of a relative egg consumption index by the predator populations (Köster et al., 2001b).

A substantial predation by adult herring on young of the year sprat was reported by Patokina and Feld- man (1998) in Sub-division 26 in autumn 1997. This predation has been related to the outstanding high abundance of young of the year sprat in the area and might be supported by a small average size of sprat due to low growth rates (ICES, 1998).

Recent studies have demonstrated that the species composition in the mesozooplankton community of the Central Baltic, and thus the availability of potential prey for larvae and early juveniles, have undergone substantial changes in the last two decades. Pseudocalanus elongatus depends strongly on high salinity (Ojaveer et al., 1998; Vuorinen et $a l ., 1998$ ) and on low temperature in summer (Möllmann et al., 2000). Both factors developed in an unfavourable direction for this species and led to a reduction of the standing stock throughout the stagnation period of the 1980s. In contrast, the copepods Temora longicornis and Acartia spp. as well as cladocerans show a strong preference for higher temperatures and an affinity for lower salinities in spring (Sidrevics, 1984, Möllmann et al., 2000), and thus developed increasing standing stocks throughout the late 1980s and early 1990s. It has been hypothesised that the abundance of nauplii and copepodid stages of T. longicornis and Acartia spp. is of importance for the survival of larval sprat (Grauman and Yula, 1989; Kalejs and Ojaveer, 1989), while corresponding juvenile life stages of $P$. elongatus may be of importance for cod larvae.

\section{MATERIAL AND METHODS}

According to the availability of time-series data, the exploratory analysis for cod is mainly restricted to Sub-division 25, comprising the Bornholm Basin (Fig. 1), currently the most important spawning ground in the Central Baltic (MacKenzie et al., 2000; Köster et al., 2001b). For sprat the exploratory analysis was restricted to the eastern spawning areas in Sub-division 26 (Gdansk Deep) and Subdivision 28 (Gotland Basin) (Fig. 1).

\section{Stock parameters}

\section{Stock size and spawning stock biomass}

Stock abundances were obtained from spatially dis-aggregated MSVPA runs for the period 19761996 (Köster et al., 2001a). Weight at age in the catch was assumed to be equal to weight at age in the stock, exceptions being age-groups 0 to 2 for 
cod. Here, due to size selection by commercial gears, period specific (before 1989 and after 1990) average weights compiled by ICES (1999b) were applied in the different areas. Cod spawning stock biomass values (SSB) were determined for the different Sub-divisions by using area specific sex ratios and maturity ogives (proportions of sexually mature individuals at age) given by Tomkiewicz et al. (1997). In cases of adequate sampling, annual values were applied, i.e. for 1986 - 1996 in Sub-division 25 and for 1993 - 1996 in Sub-division 26; otherwise 5 year averages were used (Tomkiewicz et al., 1997). To demonstrate the effect of introducing year and sex specific maturity ogives on SSB estimates as a measure of egg production, two additional options were tested: i) average maturity ogives utilised in former standard stock assessment (ICES, 1996), being invariate over time and ii) temporally and spatially resolved female SSB, based on above described information. For sprat, sex specific maturity ogives and sex ratios were available only for the most recent 5 years in Sub-division 26. This restricted the analysis to a test on the deviation between total and female SSB applying average sex specific maturity ogives and sex ratios.

\section{Abundance of recruits}

Cod recruits to the fishery at an age of 2 and year-class strength is difficult to assess at an earlier age due to cannibalism effects. Thus, regular single species assessments of cod cover age 2 as the youngest age-group and presentations of stockrecruitment relationships refer in general to agegroup 2 . In the present study, spatially dis-aggregated MSVPA runs (Köster et al., 2001a) have been utilised to estimate 0 - and 1-group abundances, thus explicitly considering cannibalism in the estimation procedure. The cod 0-group estimate for 1996 was omitted from further analysis, as it depended heavily upon the tuning method employed. For sprat, standard stock assessment procedures estimate recruitment at age 1 (ICES, 1999a), using predation mortalities derived from spatially aggregated MSVPA runs (ICES, 1999b). In the present study, 0group estimates from area dis-aggregated MSVPA runs have been utilised as a measure of reproductive success, in order to dis-entangle the impact of predation by cod on young of the year sprat from other processes affecting recruitment.

Juvenile abundance estimates derived by MSVPA runs have been validated by area specific survey indices. For cod age-groups 1 and 2, results from international bottom trawl surveys conducted since the early 1980s have been applied as compiled by the EU-project CORE (1998). For sprat, estimates of 0 - and 1-group abundances were recompiled from international hydroacoustic surveys, performed since 1981, and corrected for variation in area coverage (ICES, 1997). Results from the 1993 hydroacoustic survey were excluded, due to technical problems and lack of area coverage (ICES, 1994). It should be noted, that data series for cod age-groups 1 and 2 as well as sprat age-group 1 were utilised for tuning of the MSVPA, thus not being strictly independent. However, the impact is mainly restricted to the later part of the time series, which makes these data valid for a comparison of trends for the major part of the time series. A further validation of cod age 2 recruitment was performed using independent Latvian bottom trawl surveys conducted in Sub-division 26 and 28 in January and November/December. However, these surveys cover only a part of the time series, mainly the 1980s. Independent recruitment estimates for sprat were available from the Polish young fish survey in Sub-division 26 (ICES, 1999a) comprising a geometric mean abundance index, based on catch rates of age-groups 0 and 1.

\section{Potential egg production by the spawning stocks}

The area-specific potential egg production has been estimated for cod from female SSB per Subdivision, coupled with predicted relative individual fecundity values (Kraus et al., 2000). The relative fecundity is independent of body size and did not differ among areas though being variable among years. It was predicted as a common value for all Sub-divisions from a statistical model which includes as impact factors: average ambient temperature in the $4^{\text {th }}$ quarter of the year preceding the investigated spawning period and the anomaly in growth of average wet weight from the $3^{\text {rd }}$ quarter of the preceding year to the $1^{\text {st }}$ quarter of the year of spawning (Kraus et al., 2000). As an alternative approach, a time series of observed relative individual fecundity values was utilised (Shapiro, 1990; Bleil and Oeberst, 1996; Kraus et al., 2000), in which missing values were substituted by linear interpolation.

For sprat, available information on batch fecundity and spawning frequency (Petrowa, 1960; Polivaiko, 1980; Alekseeva et al., 1997) hardly allows to 
construct a reliable time series of potential egg production values. In this case, a proxy for the nutritional condition and the reproductive potential of the population was obtained from the anomaly in average growth rate over age-groups 2 to 4 from the $3^{\text {rd }}$ quarter of the preceding year to the $2^{\text {nd }}$ quarter of the year of spawning. In addition, the pre-spawning condition of these fish was characterised by the anomaly in weight at age in the $1^{\text {st }}$ quarter of the year of spawning. Basin specific quarterly weight at age values of adult fish have been compiled for both species by ICES (1999b), but a full analysis could be achieved for Sub-division 26 only.

\section{Egg and larval abundance}

Mean annual values for egg and larval abundance were available for the different Sub-divisions (water depths $>60 \mathrm{~m}$ ) from ichthyoplankton surveys carried out in 1976-1996. For cod, the data have been summarised by Köster et al. (2001b) and for sprat they were compiled from Krenkel (1981), Grauman and Krenkel (1986), Karasiova (1999), Köster and Möllmann (2000a). Abundance estimates for cod eggs were based on sampling during a three-month period encompassing the main spawning season, averaging survey specific mean abundance values. Up to 1989 the sampling period was April-June; thereafter it successively shifted to May-June (1990-1992) and June-August (1993-1996), corresponding to the observed shift in the cod spawning period in recent years (Wieland et al., 2000).

Abundance estimates for sprat eggs refer to the main spawning period, May-June (ICES, 1976). The periods considered for larval abundance estimates were the same as for eggs in the case of sprat, with fast egg development (Thompson et al., 1981), but were shifted for cod to account for a 2 to 4 week period of egg development (Wieland et al., 1994).

\section{Realised egg production}

Estimates of the average daily egg production during main spawning periods were based on stage specific abundance data (see above) and temperature related egg development rates (cod: Wieland et al., 1994; sprat: Thompson et al., 1981). For cod, the relevant temperatures were taken from the depth of the centre of mass of egg distribution and were obtained either from direct observations, i.e. CTDmeasurements taken concurrently to the vertically resolving ichthyoplankton sampling in 1986-1996
(Wieland and Jarre-Teichmann, 1997), or from the ICES hydrographic database and predicted centre of mass values (Köster et al., 2001b).

The vertical distribution of sprat eggs has been less intensively studied and appears to be more variable (Müller, 1988; Wieland and Zuzarte, 1991), with a typical deep distribution in spring and early summer and a more surface-oriented distribution in summer (Herra and Grimm, 1983; Herra, 1988). As the main spawning season for sprat was May/June it was assumed that the average temperature in the $60-80 \mathrm{~m}$ depths layer was most relevant for estimating developmental periods. Finally, stage specific daily egg production rates were calculated by dividing the abundance values for individual egg stages by the development time of the respective stage.

\section{Environmental factors}

\section{Oxygen concentration}

The relevance of the oxygen condition for cod egg survival was tested by including the reproductive volume (RV), defined by Plikshs et al. (1993), in the analysis as an index of potential cod egg survival. RVvalues for the different Sub-divisions and for peak spawning periods were derived from MacKenzie et al. (2000). As this index is based on minimum oxygen requirements only, two alternative indices were defined and tested in addition for a more complete utilisation of the given information about ambient oxygen conditions in the Bornholm Basin. The first one, the integrated oxygen content in the RV (ORV), is based on an integration of the mean oxygen concentrations per 1 metre depth interval throughout the thickness of the RV (MacKenzie et al., 2000).

The second alternative, the oxygen related egg survival (OES) is based on the fraction of the egg production expected to survive each year when a laboratory established relation of egg survival is applied to oxygen concentration (Rohlf, 1999), using observed oxygen profiles during spawning time and depth stratified abundance data of cod eggs. The depth distribution of eggs was predicted from the observed water density profiles (Köster et al., 2001b).

\section{Temperature}

The impact of temperature on survival of sprat eggs and larvae was tested on the basis of average 
water temperatures at main spawning time in May derived from the ICES hydrographic database. For the Bornholm Basin (Sub-division 25) and the Gdansk Deep (Sub-division 26) a depth range of 40$60 \mathrm{~m}$ was considered, and for the Gotland Basin (Sub-division 28) a range of 40-80 m was considered, corresponding to the deeper location of the permanent halocline. Temperature conditions in the intermediate water and the upper halocline in May were chosen, as they comprise the water layer with lowest temperatures and are closely related to winter temperature in the upper water column, thus representing also an index for the severity of the winter condition that potentially affects sprat condition, maturation and fecundity.

\section{Wind}

The impact of wind conditions on transport of cod larvae into suitable nursery areas or retention within the spawning areas has been examined by Köster $e t$ al. (2001b), who developed a larval transport index as a proxy for this effect. To test whether wind-induced transport affects the sprat larval abundance estimates from ichthyoplankton surveys, a larval transport index was developed corresponding to the one described for cod (Köster et al., 2001b), but adjusted to the differences in vertical distribution and main spawning season of the two species. A potential impact on sprat egg mortality and the effect of turbulence on feeding success of sprat larvae was tested using the anomalies in weekly-averaged wind speed in May/June 1977-1994 recorded at Christiansø (10 $\mathrm{nm}$ northeast of the main island of Bornholm).

\section{Predation}

Predation pressure on cod eggs was introduced into the analysis as a relative egg predation index, expressing consumption per standing stock of eggs scaled to the potential egg production according to Köster et al. (2001b). Predation on sprat by herring during the development from the larval to the 0-group stage was tested in Sub-division 26 for size-dependent effects by relating mortality rates to weight at age anomalies of 0 -group sprat during the $4^{\text {th }}$ quarter of the year, using data compiled by ICES (1999b).

\section{Prey availability}

The relevance of long term changes in zooplankton species composition for larval and 0-group sur- vival of cod and sprat was tested by utilising stagespecific data on abundance of major mesozooplankton species in Sub-division 26 and 28 during the main spawning periods, compiled by the Latvian Fisheries Research Institute (LATFRI). For a description of the sampling and analyses procedures see Möllmann et al. (2000). Selection of an appropriate prey spectrum according to prey species and stage was conducted on the basis of diet compositions described in Zuzarte et al. (1996). For cod, the test was restricted to Sub-division 26, as the number of years in which cod larvae were encountered in Sub-division 28 was too low to conduct any statistical analysis.

\section{Construction and validation of stock-recruitment models}

Our stock-recruitment relationships explicitly consider environmental and spatial heterogeneity incorporating causal relationships between survival rates of different critical life stages, environmental factors and species interactions. For cod we tested existing environmentally sensitive stock-recruitment relationships (Köster et al., 2001b) by predicting year-class strength 1996-1999, which was not considered in the parameter estimation, and subsequently comparing it to updated MSVPA results and trawl survey derived recruitment indices. Input data were: i) potential egg production by the spawning stock derived from updated area dis-aggregated MSVPA runs (ICES, 2001a), sex ratios and maturity ogives (ICES, 1998), and relative fecundity values (STORE, 2001), ii) RV and ORV calculated from hydrographic data recorded on ichthyoplankton surveys (STORE, $2000)$, iii) predation on cod eggs estimated on the basis of the vertical overlap index (Köster et al., 2001b) determined from the above hydrographic data, egg abundance from ichthyoplankton surveys and predator abundance from updated MSVPA according to Köster and Möllmann (2000a), and iv) the updated larval transport index (STORE, 2001). A similar test was conducted for stock-recruitment relationships established for sprat utilising also area disaggregated MSVPA output to determine the SSB (ICES, 2001a) and temperature conditions in the intermediate water in May extracted from the ICES hydrographic database. Predicted recruitment at age 0 was compared to MSVPA output and autumn hydroacoustic survey results (ICES, 1998, 1999a, 2000). 

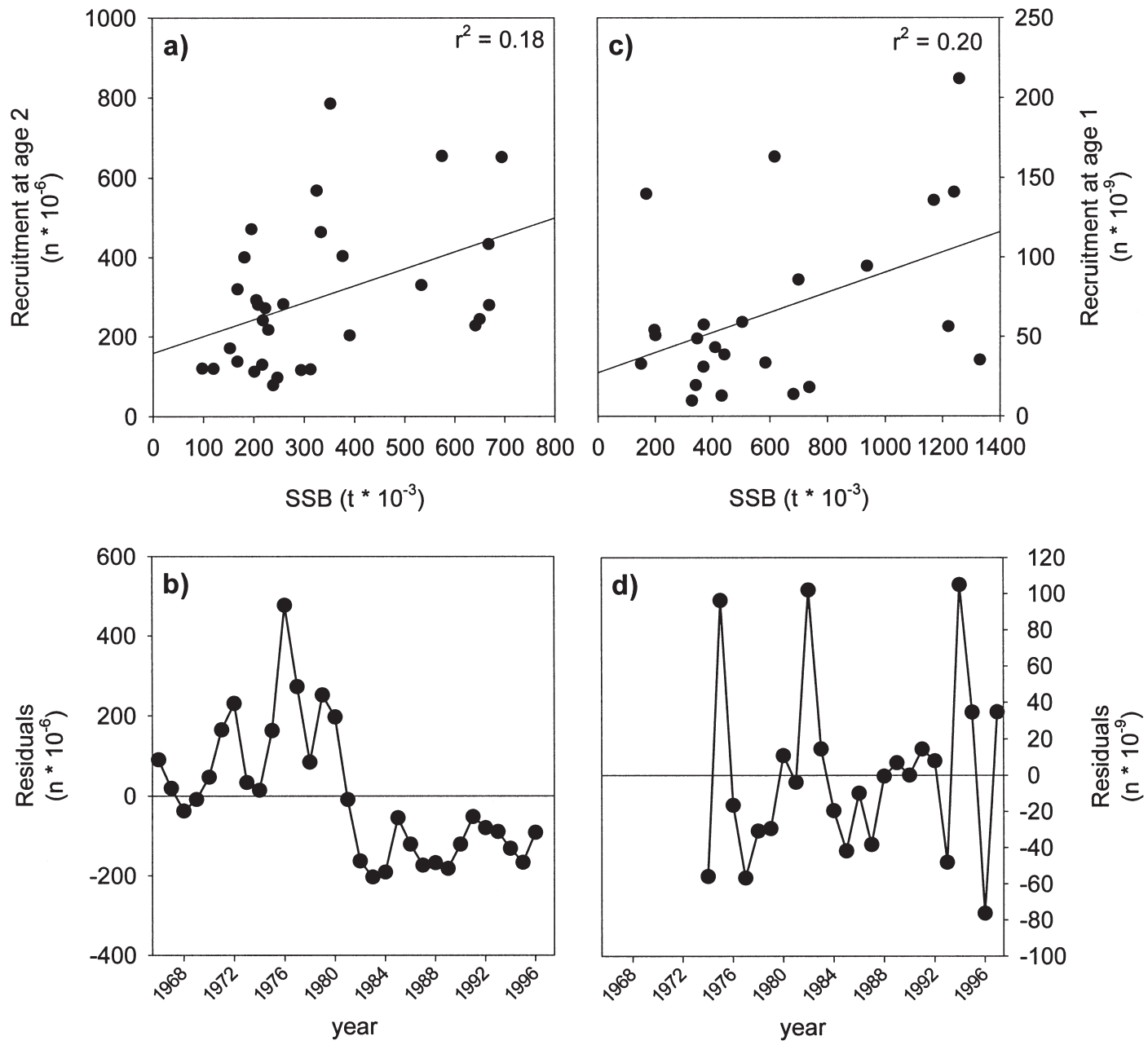

FIG. 2. - Linearity of stock-recruitment relationships of eastern Baltic cod (Sub-division 25-32) (a) and Baltic sprat (Sub-division 22-32) (c) and corresponding residuals (b and d), data source: standard stock assessment (ICES 1999a).

\section{RESULTS}

\section{Significance of linear stock-recruitment relationships}

Linear regression analyses revealed significant relationships between spawning stock biomass and recruitment of cod and sprat as determined by the standard stock assessment for the eastern and the entire Baltic respectively (Fig. 2). However, the explained variance in recruitment at age 2 and 1 is low, with a significant intercept for cod and high outlying recruitment values for both species. Furthermore, there is a clear time trend in the residuals for cod with a high number of positive residuals at the beginning of the time series up to 1981 and only negative residuals afterwards (Fig. 2). The stockrecruitment relationships derived by the area disaggregated MSVPA runs show a corresponding pattern for cod with a significant linear relationship in Sub- divisions 26 and 28, but not in Sub-division 25 (Table 1). Again, high recruitment success originated from intermediate SSB at the beginning of the time series. Recruitment declined despite high SSB in the early 1980s. This pattern resulted in a significant auto-correlation in the residuals. For sprat a significant linear relationship was obtained only for Sub-division 25 (Table 1), while in the other areas an outstanding high recruitment of the 1982 yearclass originating from a low SSB did not coincide with a linear relationship (Fig. 2).

\section{Validation and improvement of stock-recruitment relationships}

\section{Spawning stock biomass as a measure of egg production}

When using constant maturity ogives over time, the SSB calculated for cod in Sub-division 25 was 
TABLE 1. - Linear regressions of cod and sprat recruitment (in numbers) on SSB (in t) derived by area dis-aggregated MSVPA for different Sub-divisions (SSB in t): parameter estimates and their significance level, $\mathrm{r}^{2}$-values and Durbin Watson (DW) statistics indicating serial correlation in the residuals if significant $(*=$ significant at $5 \%$ level).

\begin{tabular}{|c|c|c|c|c|c|c|c|}
\hline \multicolumn{2}{|c|}{ Dependent variableSub-division } & \multirow{2}{*}{$\begin{array}{c}\text { Time series } \\
1976-96\end{array}$} & \multirow{2}{*}{$\begin{array}{c}\text { Parameter } \\
\text { slope } \\
\text { intercept }\end{array}$} & \multirow{2}{*}{$\begin{array}{c}\text { Parameter estimates } \\
815.0 \\
7.521 * 10^{7}\end{array}$} & \multirow{2}{*}{$\begin{array}{c}\mathrm{p} \\
0.091 \\
0.101\end{array}$} & \multirow{2}{*}{$\frac{\mathrm{r}^{2}}{0.16}$} & \multirow{2}{*}{$\begin{array}{c}\text { DW statistics } \\
0.61^{*}\end{array}$} \\
\hline Cod age 2 & 25 & & & & & & \\
\hline Cod age 2 & 26 & 1976-96 & $\begin{array}{c}\text { slope } \\
\text { intercept }\end{array}$ & $\begin{array}{c}869.5 \\
2.825 * 10^{7}\end{array}$ & $\begin{array}{l}0.037 \\
0.037\end{array}$ & 0.23 & $0.43^{*}$ \\
\hline Cod age 2 & 28 & 1976-94 & $\begin{array}{c}\text { slope } \\
\text { intercept }\end{array}$ & $\begin{array}{c}1097.1 \\
3.612 * 10^{6}\end{array}$ & $\begin{array}{l}0.003 \\
0.810\end{array}$ & 0.41 & $0.49 *$ \\
\hline Sprat age 1 & 25 & $1977-96$ & $\begin{array}{c}\text { slope } \\
\text { intercept }\end{array}$ & $\begin{array}{c}67645 \\
1.167 * 10^{10}\end{array}$ & $\begin{array}{l}0.003 \\
0.043\end{array}$ & 0.43 & 1.44 \\
\hline Sprat age 1 & 26 & $1977-96$ & $\begin{array}{c}\text { slope } \\
\text { intercept }\end{array}$ & $\begin{array}{c}43017 \\
7.547 * 10^{9}\end{array}$ & $\begin{array}{l}0.198 \\
0.163\end{array}$ & 0.10 & 1.93 \\
\hline Sprat age 1 & 28 & $1977-96$ & $\begin{array}{c}\text { slope } \\
\text { intercept }\end{array}$ & $\begin{array}{c}29529 \\
-4.309 * 10^{9}\end{array}$ & $\begin{array}{l}0.197 \\
0.197\end{array}$ & 0.10 & 2.19 \\
\hline
\end{tabular}

not linearly related to the daily egg production at peak spawning time, but it was significantly related if based on yearly or periodically adapted maturity ogives (Table 2). The relationship was further enhanced when only the female part of the SSB or the predicted potential egg production were used. The largest deviations between potential and realised egg production were apparent for the most recent years of the time series. Utilising observed instead of predicted relative fecundity values, which included a linear interpolation procedure for missing data, also resulted in a significant relation to the realised egg production, but with a slightly higher unexplained variance $\left(\mathrm{r}^{2}=0.39, \mathrm{p}=0.001\right)$.

For sprat in Sub-divisions 26 and 28, the results were different: the SSB was significantly related to the realised egg production even when it was based on constant maturity ogives over time (Table 2). Utilising an age-specific sex ratio invariate with time to compute the female SSB in Sub-division 26 did not further enhance the relationship $\left(r^{2}=0.42\right.$, $p$ $=0.003)$. Female and total SSB were closely related $\left(r^{2}=0.98\right)$, although the sex ratio was rather skewed to female dominance with increasing age.

TABLE 2. - Linear regressions of realised egg production of cod and sprat on different measures of potential egg production. Realised egg production $=$ average production of stage I eggs $\left(n^{*} d_{a y}^{-1}\right)$ during the main spawning season derived from ichthyoplankton surveys. Measures of potential egg production are based on alternative estimates for SSB (in t) and include fecundity information in one option. The table presents parameter estimates and their significance levels, $\mathrm{r}^{2}$-values and Durbin Watson (DW) statistics indicating serial correlation in the residuals if significant $(*=$ significant at $5 \%$ level $)$.

\begin{tabular}{|c|c|c|c|c|c|c|c|}
\hline Independent variable & Sub-division & Time series & Parameter & Parameter estimates & $\mathrm{p}$ & $\mathrm{r}^{2}$ & DW statistics \\
\hline $\begin{array}{l}\text { cod SSB based on maturity } \\
\text { ogive invariate with time }\end{array}$ & 25 & $\begin{array}{c}1976-96 \\
\text { without } 1979-82 \& 1984^{1)}\end{array}$ & $\begin{array}{l}\text { slope } \\
\text { intercept }\end{array}$ & $\begin{array}{c}344.74 \\
4.6970 * 10^{10}\end{array}$ & $\begin{array}{r}0.488 \\
<0.414\end{array}$ & 0.03 & $0.63^{*}$ \\
\hline $\begin{array}{l}\text { cod SSB based on yearly or } \\
\text { period specific maturity ogives }\end{array}$ & 25 & $\begin{array}{c}1976-96 \\
\text { without } 1979-82 \& 1984^{1)}\end{array}$ & $\begin{array}{l}\text { slope } \\
\text { intercept }\end{array}$ & $\begin{array}{c}1.256 .9 \\
-1.4979 * 10^{10}\end{array}$ & $\begin{array}{r}0.027 \\
<0.734\end{array}$ & 0.30 & $0.62 *$ \\
\hline female cod SSB & 25 & $\begin{array}{c}1976-96 \\
\text { without } 1979-82 \& 1984^{1)}\end{array}$ & $\begin{array}{l}\text { Slope } \\
\text { Intercept }\end{array}$ & $\begin{array}{c}3315.5 \\
-8.2145^{*} 10^{10}\end{array}$ & $\begin{array}{r}<0.001 \\
0.048\end{array}$ & 0.61 & $1.04 *$ \\
\hline $\begin{array}{l}\text { predicted potential egg } \\
\text { production of cod }\end{array}$ & 25 & $\begin{array}{c}1976-96 \\
\text { without } 1979-82 \& 1984^{1)}\end{array}$ & $\begin{array}{l}\text { Slope } \\
\text { Intercept }\end{array}$ & $\begin{array}{l}4.6471 * * 10^{-3} \\
-7.1663 * 10^{10}\end{array}$ & $\begin{array}{r}<0.001 \\
0.054\end{array}$ & 0.63 & 1.40 \\
\hline sprat SSB & 26 & $\begin{array}{l}\text { 1977-96 } \\
\text { without } 1992^{1)}\end{array}$ & $\begin{array}{l}\text { Slope } \\
\text { Intercept }\end{array}$ & $\begin{array}{l}1.3710^{*} 10^{-4} \\
12.334\end{array}$ & $\begin{array}{l}0.002 \\
0.201\end{array}$ & 0.44 & 2.16 \\
\hline sprat SSB & 28 & $\begin{array}{c}\text { 1977-96 } \\
\text { without } 1992^{1)}\end{array}$ & $\begin{array}{l}\text { Slope } \\
\text { Intercept }\end{array}$ & $\begin{array}{l}1.9014 * 10^{-4} \\
5.9692\end{array}$ & $\begin{array}{l}0.004 \\
0.492\end{array}$ & 0.39 & 1.36 \\
\hline
\end{tabular}

1) No reliable egg production rates from ichthyoplankton surveys available. 


\section{Abundance of recruits as a measure of reproductive success}

Cod abundances at age 1 and 2, as calculated by MSVPA, were significantly related to abundance indices from the international bottom trawl survey (BITS) in all areas with the highest variability in Sub-division 25 (Table 3). In this area especially the 1979 year-class showed a low abundance index as one-year-old in the 1980 survey, which did not coincide with a high recruitment estimated by the MSVPA. In Sub-divisions 26 and 28 survey data were available only since 1981 and 1982 respectively. Thus, a validation of the MSVPA derived 1979 year-class strength was not possible for age-group 1 . However, as two-year-old the year-class was covered by the 1981 survey in Sub-division 26, again indicating that the MSVPA resulted in a substantial overestimation of the 1979 year class size. Independent abundance indices for age-group 2 from Latvian bottom trawl surveys, conducted in Sub-divisions 26 and 28 in the $1^{\text {st }}$ and $4^{\text {th }}$ quarter, also revealed a significant relationship with MSVPA results, with the exception of the $1^{\text {st }}$ quarter series in Sub-division 26 (Table 3).
For sprat, MSVPA derived recruitment estimates at age 0 were highly correlated to abundance estimates from international autumn hydroacoustic surveys in Sub-division 25, but not in the two other Subdivisions (Table 4). Here outstanding high recruitment values were determined by MSVPA for the 1982 year class, while hydroacoustic survey estimates indicated a low year-class strength. Omitting this one year-class from the analysis resulted in significant relationships for both areas (Table 4). Concerning recruitment at age 1, the MSVPA estimated again an outstanding strength for the 1982 year-class in Subdivisions 26 and 28. Apart from this, all regressions with survey indices were statistically significant (Table 4). A comparison with independent Polish young fish survey estimates in Sub-division 26 revealed a significant correlation to MSVPA derived estimates (Table 4), but with again considerable residual variability and individual outstanding differences from MSVPA estimates for the 1982 year class.

\section{Identification of critical early life history stages}

Regression analyses of daily production rates of early developmental stages on later stages during the

TABLE 3. - Linear regressions of MSVPA based cod recruitment at age 1 and 2 (in numbers) on survey based recruitment estimates for different Sub-divisions (BITS: indices, Latvian survey: $\mathrm{n}^{*} \mathrm{~h}^{-1}$ ). The table presents parameter estimates and their significance levels, $\mathrm{r}^{2}$-values and Durbin Watson (DW) statistics indicating serial correlation in the residuals if significant $(*=$ significant at $5 \%$ level).

\begin{tabular}{|c|c|c|c|c|c|c|c|}
\hline Independent variable & Sub-division & year-class & Parameter & Parameter estimates & $\mathrm{p}$ & $\mathrm{r}^{2}$ & DW statistics \\
\hline age 1 BITS & 25 & $1979-95$ & $\begin{array}{c}\text { Slope } \\
\text { Intercept }\end{array}$ & $\begin{array}{l}6.2329 * 10^{6} \\
1.4396 * 10^{8}\end{array}$ & $\begin{array}{r}0.015 \\
<0.001\end{array}$ & 0.34 & $0.68^{*}$ \\
\hline age 1 BITS & 26 & $1980-95$ & $\begin{array}{c}\text { Slope } \\
\text { Intercept }\end{array}$ & $\begin{array}{l}3.2003 * 10^{6} \\
9.1831 * 10^{7}\end{array}$ & $\begin{array}{l}<0.001 \\
<0.001\end{array}$ & 0.73 & $1.12 *$ \\
\hline age 1 BITS & 28 & $1981-95$ & $\begin{array}{c}\text { Slope } \\
\text { Intercept }\end{array}$ & $\begin{array}{c}8.3191 * 10^{6} \\
98953\end{array}$ & $\begin{array}{l}<0.001 \\
<0.001\end{array}$ & 0.88 & $0.68 *$ \\
\hline age 2 BITS & 25 & $1980-94$ & $\begin{array}{c}\text { Slope } \\
\text { Intercept }\end{array}$ & $\begin{array}{l}2.0996 * 10^{6} \\
7.5276^{*} 10^{7}\end{array}$ & $\begin{array}{l}0.001 \\
0.002\end{array}$ & 0.52 & 1.54 \\
\hline age 2 BITS & 26 & 1979-94 & $\begin{array}{c}\text { Slope } \\
\text { Intercept }\end{array}$ & $\begin{array}{l}1.2887 * 10^{6} \\
5.6251 * 10^{7}\end{array}$ & $\begin{array}{l}<0.001 \\
<0.001\end{array}$ & 0.64 & 1.82 \\
\hline age 2 BITS & 28 & 1980-94 & $\begin{array}{c}\text { Slope } \\
\text { Intercept }\end{array}$ & $\begin{array}{c}234797 \\
1.3360 * 10^{7}\end{array}$ & $\begin{array}{r}<0.001 \\
0.011\end{array}$ & 0.79 & 1.31 \\
\hline $\begin{array}{l}\text { age } 2 \text { Latvian trawl } \\
\text { survey } 1^{\text {st }} \text { quarter }\end{array}$ & 26 & $\begin{array}{l}1976-89 \text { without } \\
1978-79 \& 84^{1)}\end{array}$ & $\begin{array}{c}\text { Slope } \\
\text { Intercept }\end{array}$ & $\begin{array}{c}47181 \\
8.0621 * 10^{7}\end{array}$ & $\begin{array}{l}0.030 \\
0.080\end{array}$ & 0.30 & $0.68^{*}$ \\
\hline $\begin{array}{l}\text { age } 2 \text { Latvian trawl } \\
\text { survey } 1^{\text {st }} \text { quarter }\end{array}$ & 28 & $\begin{array}{l}1976-90 \text { without } \\
1978 \& 89^{1)}\end{array}$ & $\begin{array}{c}\text { Slope } \\
\text { Intercept }\end{array}$ & $\begin{array}{c}54798 \\
2.8730 * 10^{7}\end{array}$ & $\begin{array}{r}<0.001 \\
0.008\end{array}$ & 0.74 & $1.15^{*}$ \\
\hline $\begin{array}{l}\text { age } 2 \text { Latvian trawl } \\
\text { survey } 4^{\text {th }} \text { quarter }\end{array}$ & 26 & $\begin{array}{c}1976 \& 1980-87 \\
\text { without } 1985^{1)}\end{array}$ & $\begin{array}{c}\text { Slope } \\
\text { Intercept }\end{array}$ & $\begin{array}{c}125256 \\
6.5177 * 10^{7}\end{array}$ & $\begin{array}{l}0.023 \\
0.076\end{array}$ & 0.61 & 2.23 \\
\hline $\begin{array}{l}\text { age } 2 \text { Latvian trawl } \\
\text { survey } 4^{\text {th }} \text { quarter }\end{array}$ & 28 & $1979-87$ & $\begin{array}{c}\text { Slope } \\
\text { Intercept }\end{array}$ & $\begin{array}{c}50352 \\
3.1662 * 10^{7}\end{array}$ & $\begin{array}{l}0.001 \\
0.005\end{array}$ & 0.79 & 1.23 \\
\hline
\end{tabular}

1) No surveys performed. 
TABLE 4. - Linear regressions of MSVPA based sprat recruitment at age 0 and 1 on survey based recruitment estimates (in numbers) for different Sub-divisions. The table presents parameter estimates and their significance levels, $\mathrm{r}^{2}$-values and Durbin Watson (DW) statistics indicating serial correlation in the residuals if significant $(*=$ significant at $5 \%$ level $)$.

\begin{tabular}{|c|c|c|c|c|c|c|c|}
\hline Independent variable & Sub-division & year-class & Parameter & Parameter estimates & $\mathrm{p}$ & $\mathrm{r}^{2}$ & DW statistics \\
\hline $\begin{array}{l}\text { age } 0 \text { international } \\
\text { hydroacoustic survey }\end{array}$ & 25 & $1981-96$ & $\begin{array}{l}\text { slope } \\
\text { intercept }\end{array}$ & $\begin{array}{c}8.6295 \\
2.6510^{*} 10^{10}\end{array}$ & $\begin{array}{l}<0.001 \\
<0.001\end{array}$ & 0.80 & 2.06 \\
\hline $\begin{array}{l}\text { age } 0 \text { international } \\
\text { hydroacoustic survey }\end{array}$ & 26 & $1981-96$ & $\begin{array}{l}\text { slope } \\
\text { intercept }\end{array}$ & $\begin{array}{c}0.7143 \\
2.8611 * 10^{10}\end{array}$ & $\begin{array}{l}0.349 \\
0.011\end{array}$ & 0.07 & 2.04 \\
\hline $\begin{array}{l}\text { age } 0 \text { international } \\
\text { hydroacoustic survey }\end{array}$ & 26 & $\begin{array}{c}\text { 1981-96 } \\
\text { without } 1982\end{array}$ & $\begin{array}{l}\text { slope } \\
\text { intercept }\end{array}$ & $\begin{array}{c}1.0505 \\
1.9886 * 10^{9}\end{array}$ & $\begin{array}{l}0.037 \\
0.007\end{array}$ & 0.31 & 2.19 \\
\hline $\begin{array}{l}\text { age } 0 \text { international } \\
\text { hydroacoustic survey }\end{array}$ & 28 & $1981-96$ & $\begin{array}{c}\text { slope } \\
\text { intercept }\end{array}$ & $\begin{array}{c}0.8379 \\
1.3592 * 10^{10}\end{array}$ & $\begin{array}{l}0.293 \\
0.005\end{array}$ & 0.08 & 1.92 \\
\hline $\begin{array}{l}\text { age } 0 \text { international } \\
\text { hydroacoustic survey }\end{array}$ & 28 & $\begin{array}{c}\text { 1981-96 } \\
\text { without } 1982\end{array}$ & $\begin{array}{l}\text { slope } \\
\text { intercept }\end{array}$ & $\begin{array}{c}1.1563 \\
9.9201 * 10^{9}\end{array}$ & $\begin{array}{c}0.016 \\
<0.001\end{array}$ & 0.40 & 1.90 \\
\hline $\begin{array}{l}\text { age } 1 \text { international } \\
\text { hydroacoustic survey }\end{array}$ & 25 & $1981-95$ & $\begin{array}{l}\text { slope } \\
\text { intercept }\end{array}$ & $\begin{array}{c}5.4102 \\
2.1162 * 10^{10}\end{array}$ & $\begin{array}{l}<0.001 \\
<0.001\end{array}$ & 0.68 & 1.38 \\
\hline $\begin{array}{l}\text { age } 1 \text { international } \\
\text { hydroacoustic survey }\end{array}$ & 26 & $1981-95$ & $\begin{array}{l}\text { slope } \\
\text { intercept }\end{array}$ & $\begin{array}{c}1.3676 \\
1.1497 * 10^{10}\end{array}$ & $\begin{array}{l}0.012 \\
0.146\end{array}$ & 0.42 & 2.42 \\
\hline $\begin{array}{l}\text { age } 1 \text { international } \\
\text { hydroacoustic survey }\end{array}$ & 26 & $\begin{array}{c}\text { 1981-95 } \\
\text { without } 1982\end{array}$ & $\begin{array}{l}\text { slope } \\
\text { intercept }\end{array}$ & $\begin{array}{c}1.2488 \\
9.1156 * 10^{9}\end{array}$ & $\begin{array}{l}0.001 \\
0.062\end{array}$ & 0.65 & 2.54 \\
\hline $\begin{array}{l}\text { age } 1 \text { international } \\
\text { hydroacoustic survey }\end{array}$ & 28 & $1981-95$ & $\begin{array}{l}\text { slope } \\
\text { intercept }\end{array}$ & $\begin{array}{c}0.2798 \\
9.8700 * 10^{10}\end{array}$ & $\begin{array}{l}0.002 \\
0.024\end{array}$ & 0.35 & 2.12 \\
\hline $\begin{array}{l}\text { age } 1 \text { international } \\
\text { hydroacoustic survey }\end{array}$ & 28 & $\begin{array}{c}\text { 1981-95 } \\
\text { without } 1982\end{array}$ & $\begin{array}{l}\text { slope } \\
\text { intercept }\end{array}$ & $\begin{array}{c}0.2925 \\
7.8830 * 10^{9}\end{array}$ & $\begin{array}{l}<0.001 \\
<0.001\end{array}$ & 0.79 & 1.91 \\
\hline $\begin{array}{l}\text { year-class index from } \\
\text { polish young fish survey }\end{array}$ & 28 & $\begin{array}{c}1976-96 \\
\text { without } 1995\end{array}$ & $\begin{array}{l}\text { slope } \\
\text { intercept }\end{array}$ & $\begin{array}{l}3.0927 * 10^{10} \\
1.2398 * 10^{10}\end{array}$ & $\begin{array}{l}0.009 \\
0.141\end{array}$ & 0.34 & 2.03 \\
\hline
\end{tabular}

egg to juvenile development (Table 5) indicated that in Sub-division 25 cod recruitment at age 1 (derived from MSVPA) was closely related to age $0\left(\mathrm{r}^{2}=\right.$ 0.98 ), and age 0 recruitment was significantly related to larval abundance $\left(r^{2}=0.64\right)$. Critical periods appeared to be the late egg to larval stage $\left(r^{2}=0.13\right)$ and somewhat less the egg stage I to III $\left(r^{2}=0.26\right)$. The oldest egg stage IV was not considered as its abundance is highly variable due to a relatively short stage duration and the hatching process, which in Baltic cod commences during this stage (Wieland et al., 1994). The lowest egg survival rates were estimated for the first half of the 1980s (i.e. 1983 and 1985), though this is a period in which the amount of missing data was greatest. Larval abundance per egg stage III production was lowest in the period 1992 to 1996, indicating extremely low viable hatch or larval survival in these years.

For sprat, the relations between production estimates of early and late egg stages as well as between late egg stage production and larval abundance were highly significant for Sub-divisions 26 and 28. This indicates that mortality during the egg and early larval stage is less critical for the reproductive success of sprat compared to cod (Table 5). In contrast to cod the 0-group abundance of sprat was hardly related to the larval abundance, even when the 1982 year-class, which was most likely overestimated by the MSVPA (Sub-division 26: $\mathrm{r}^{2}=0.16,28: \mathrm{r}^{2}=$ 0.08 ) was excluded from the analysis. But similar to cod, recruitment at age 0 and age 1 estimated by MSVPA were closely related.

\section{Processes affecting critical early life history stages}

\section{Cod survival during the egg stage}

The daily production of stage III cod eggs during the main spawning time divided by the total potential egg production from SSB was used as the best estimate of the actual egg survival rate in Sub-division 25 . A statistically significant linear regression of this "actual survival rate" on the oxygen related egg survival (OES) index was obtained $(\mathrm{p}=0.005)$, and explained $44 \%$ of the variance encountered (Fig. 3); however, pronounced negative residuals were apparent for 1983 and 1985 and positive residuals in 
TABLE 5. - Linear regression of abundance or production estimates of individual life stages on the abundance or production of the succeeding life stage of cod and sprat. The table presents $\mathrm{r}^{2}$-values and significance levels.

\begin{tabular}{|c|c|c|c|c|c|}
\hline Independent variable & Dependent variable & Sub-division & Time series & $\mathrm{r}^{2}$ & $\mathrm{p}$ \\
\hline \multicolumn{6}{|l|}{$\operatorname{cod}$} \\
\hline realised egg production (stage I) & late egg production (stage III) & 25 & $\begin{array}{l}\text { 1976-96 without } \\
1979-82 \& 1984^{1)}\end{array}$ & 0.26 & 0.044 \\
\hline late egg production (stage III) & larval abundance & 25 & $\begin{array}{l}\text { 1976-96 without } \\
1979-82 \& 1984^{1)}\end{array}$ & 0.13 & 0.173 \\
\hline larval abundance & 0 -group recruitment & 25 & $1976-95$ & 0.64 & $<0.001$ \\
\hline 0 -group recruitment & 1-group recruitment & 25 & $1976-95$ & 0.98 & $<0.001$ \\
\hline \multicolumn{6}{|l|}{ sprat } \\
\hline realised egg production (stage I) & late egg production (stage III) & 26 & $\begin{array}{c}1973-96 \\
\text { without } 1992^{1)}\end{array}$ & 0.67 & $<0.001$ \\
\hline late egg production (stage III) & larval abundance & 26 & $\begin{array}{c}1973-96 \\
\text { without } 1992^{1)}\end{array}$ & 0.66 & $<0.001$ \\
\hline larval abundance & 0 -group recruitment & 26 & $1977-96$ & 0.01 & 0.617 \\
\hline 0 -group recruitment & 1-group recruitment & 26 & $1977-95$ & 0.98 & $<0.001$ \\
\hline realised egg production (stage I) & late egg production (stage III) & 28 & $\begin{array}{c}\text { 1973-96 } \\
\text { without } 1992^{1)}\end{array}$ & 0.80 & $<0.001$ \\
\hline late egg production (stage III) & larval abundance & 28 & $\begin{array}{c}1973-96 \\
\text { without } 1992^{1)}\end{array}$ & 0.23 & 0.020 \\
\hline larval abundance & 0 -group recruitment & 28 & $1977-96$ & $<0.01$ & 0.824 \\
\hline 0 -group recruitment & 1-group recruitment & 28 & $1977-95$ & 0.96 & $<0.001$ \\
\hline
\end{tabular}

1) No reliable egg production rates from ichthyoplankton surveys available.

1976, 1978 and 1994. Utilising the egg consumption index to explain variability in actual egg survival revealed a negative linear relationship explaining $21 \%$ of the variance, but it was not statistically significant $(\mathrm{p}=0.078)$. A high scatter in egg survival was obvious for low consumption indices with the highest residuals in the outlying years identified above (Fig. 3). When both processes were applied as impact factors on the potential egg production, i.e. subtracting the consumed from the potential egg production and multiplying by the OES similar to the procedure in Köster et al. (2001b), the observed daily stage III egg production was significantly related to this combined predictive index $\left(r^{2}=0.60\right.$, $\mathrm{p}<0.001$, Fig 3). The potential egg production alone explained $30 \%$ of the variance in stage III cod egg production. Again, difficulties in explaining the low stage III egg production in 1983 were encountered. Utilisation of the alternative time series of potential egg production based on actual fecundity measurements confirmed the significant impact of oxygen conditions in deep water layers on egg survival $\left(r^{2}=0.30, p=0.027\right)$, but the impact of egg predation $\left(\mathrm{r}^{2}=0.16, \mathrm{p}=0.122\right)$ was less clear. Applying both processes as impact factors on the potential egg production as above, but based on actually measured fecundity values instead of pre- dicted ones, resulted in the same quality of linear relationship to the observed egg production at stage III $\left(\mathrm{r}^{2}=0.61, \mathrm{p}<0.001\right)$.

\section{Cod survival to larval stage}

The potential egg production, based on predicted relative fecundity values, was linearly related to larval abundance (Fig. 4a) only if the three most recent years were removed from the regression analysis $\left(r^{2}\right.$ $=0.29, \mathrm{p}=0.022)$. Compared to the high potential egg production in these years, the observed larval abundance was much lower than expected. Utilising the averaged daily production of stage III eggs instead of the potential egg production did improve the above relationships somewhat, but again only being significant if 1994 to 1996 were omitted from the analysis $\left(r^{2}=0.32, p=0.043\right)$.

When the ratio of larval abundance to the predicted potential egg production was used as a measure of survival to the larval stage, no significant linear relation of this survival to the OES index or to the egg consumption index was obtained, regardless of whether the most recent three years were considered or not ( $\mathrm{r}^{2}$ between 0.04 to 0.10$)$. Using the ORV provided a better but still insignificant relationship $\left(r^{2}=0.16, p=0.073\right)$. Pronounced negative residu- 

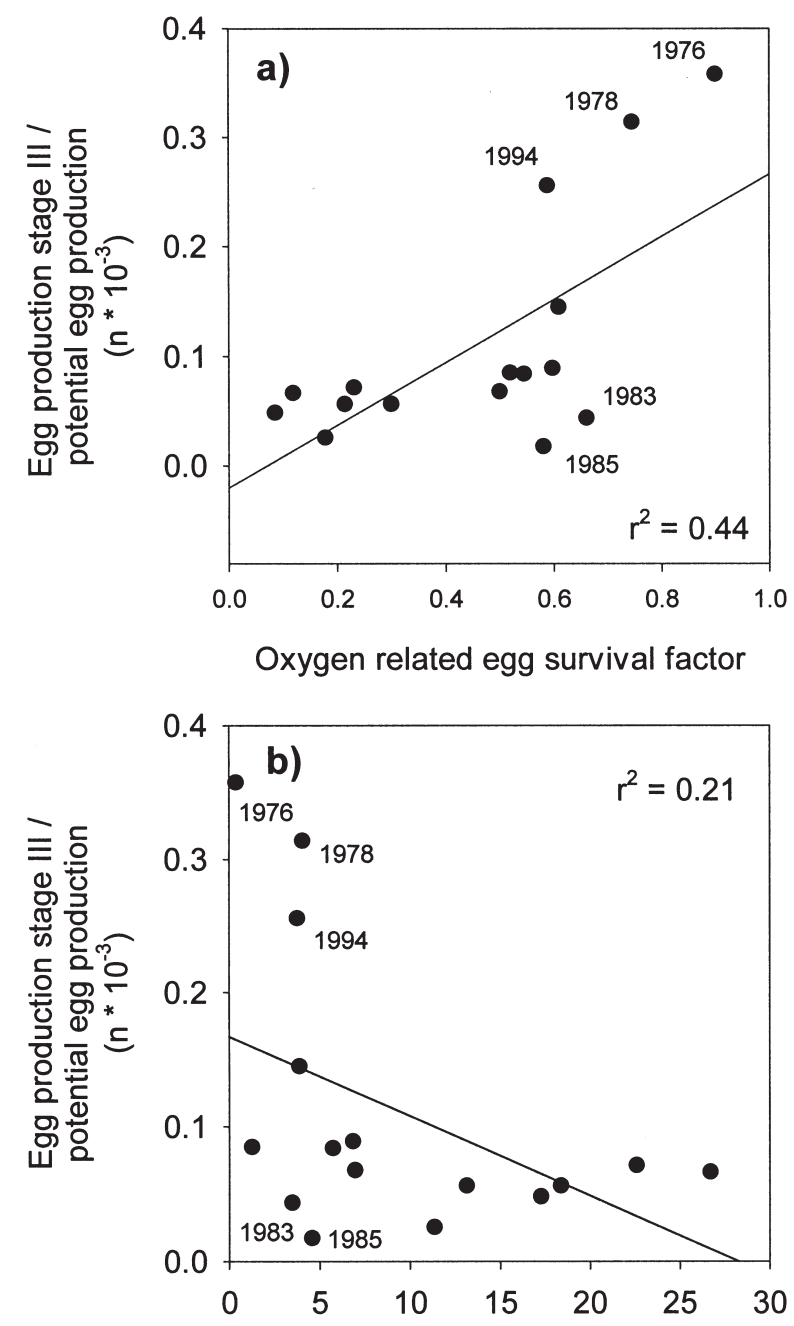

Egg consumption index

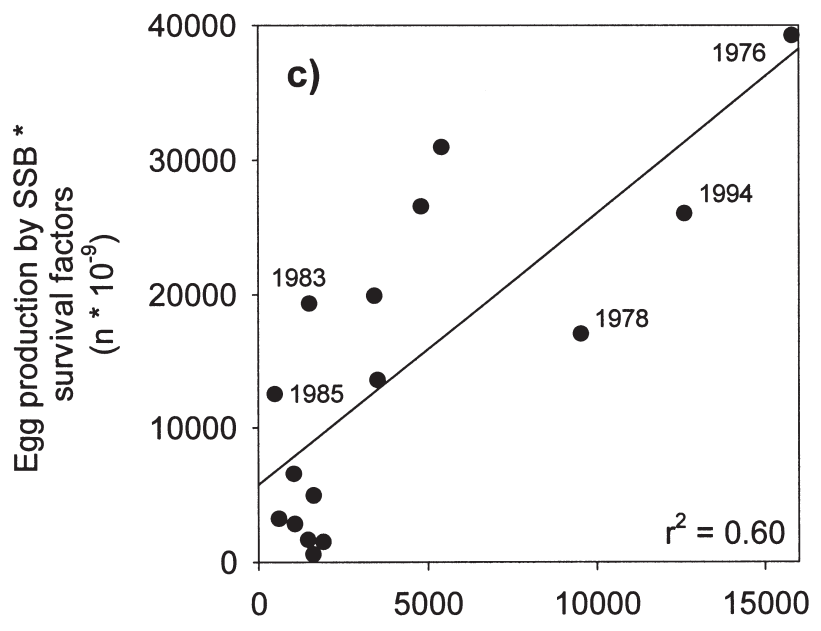

Egg production stage III

$$
\left(n * 10^{-6}\right)
$$

FIG. 3. - Linear regressions of daily cod egg production at stage III in Sub-division 25 per unit of egg production by SSB (as a measure of egg survival) on oxygen related relative egg survival (a) and on an index of cod egg consumption (b); linear regression of daily egg production at stage III on potential egg production corrected for oxygen related mortality and egg consumption (c).

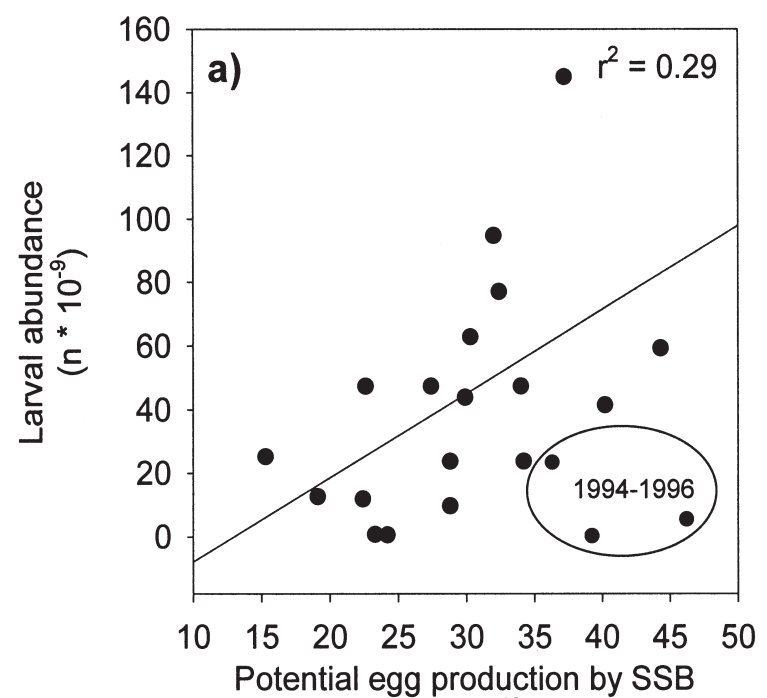

$\left(n * 10^{-12}\right)$

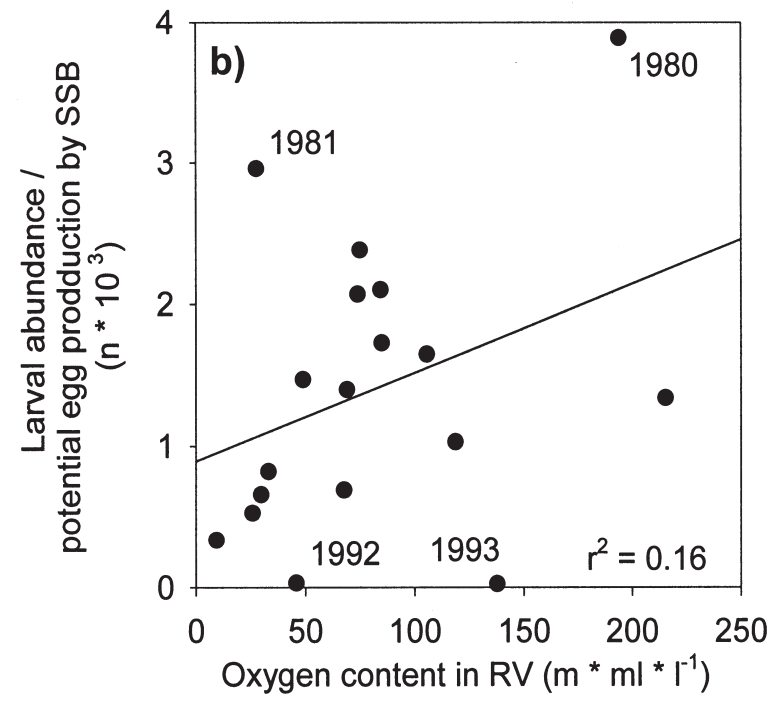

FIG. 4. - Linear regressions of cod larval abundance on potential egg production by SSB in Sub-division 25 (a), indicated data for 1994-1996 removed; linear regression of larval abundance per unit of potential egg production by SSB on oxygen content in the reproductive volume (ORV) (b).

als were apparent in 1992 and 1993 and high positive residuals in 1980 and 1981 (Fig. 4b). Replacing the potential egg production by the late egg stage production did not improve the relationships.

In order to test the impact of food availability for first feeding cod larvae in combination with hydrographic conditions, i.e. oxygen content in the bottom water, Sub-division 26 was used as a test case. The ratio of larval abundance to the potential egg production (based on observed relative fecundity) was significantly related to nauplii abundance in May/June $\left(\mathrm{r}^{2}=0.33, \mathrm{p}=0.020\right)$. However, since 1988 larval abundance values were zero indepen- 


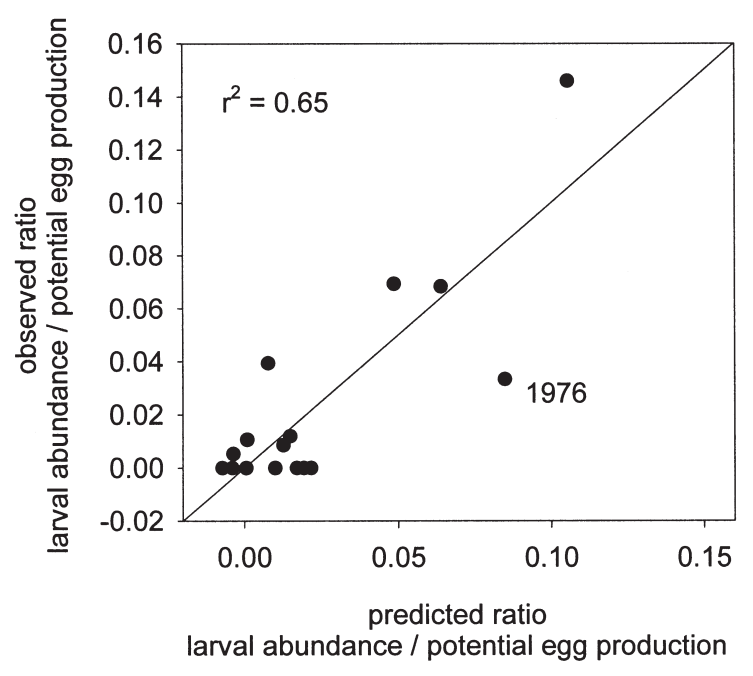

FIG. 5. - Cod larval abundance per unit of potential egg production by SSB in Sub-division 26 and predicted by a multiple linear regression model utilising nauplii abundance and reproductive volume during main spawning time as independent variables.

dent of the prey availability, probably due to unfavourable hydrographic conditions. To consider the impact of hydrography, the reproductive volume in Sub-division 26 was incorporated into a multiple linear regression analysis. This exercise resulted in $65 \%$ explained variance in the ratio of larval abundance to the potential egg production (Fig. 5), with both independent variables being significant $(p=0.002$ for the $R V$ and $p=0.027$ for nauplii abundance).

\section{Sprat egg production}

The relationships between realised egg production and sprat SSB described above did not explain major parts of the variance. Thus, we made an attempt to identify processes influencing the egg production of sprat. For Sub-division 26, the average weight at age anomaly in pre-spawning times and growth rate anomalies covering the period during autumn and winter months were tested as proxies for the nutritional condition of the adults. Additionally, the impact of low temperatures in the intermediate water in May/June was tested. The egg production was not significantly related to any one of these factors alone. However, incorporated into a multiple regression, the SSB, the temperature in the intermediate water and either growth or weight at age anomaly resulted in significant statistical models (Fig. 6). A major proportion (63\%) of the variation was explained by the following combination of variables: SSB $(p=0.003)$, tem-

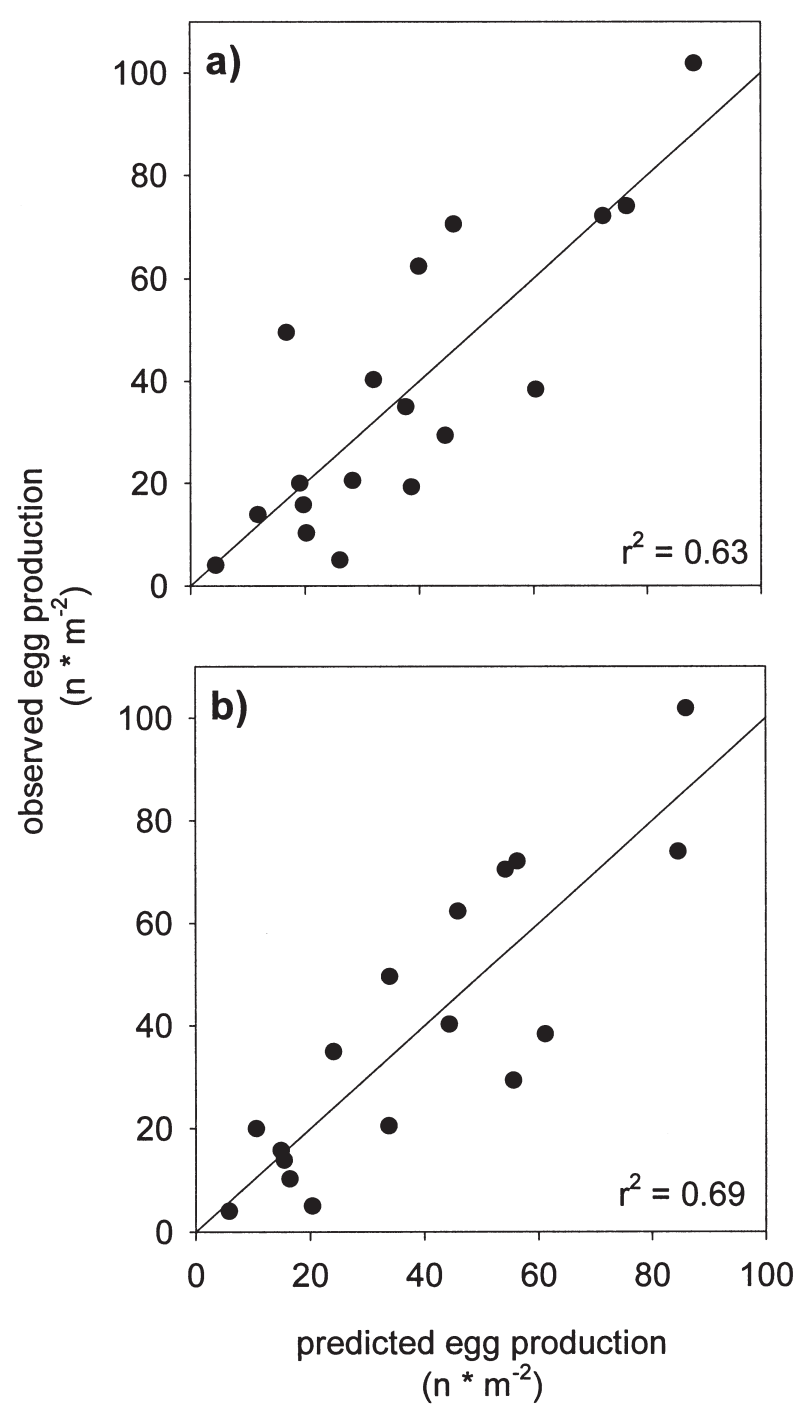

FIG. 6. - Realised egg production of sprat in Sub-division 26 from ichthyoplankton surveys versus predicted by a multiple linear regression model utilising spawning stock biomass, weight at age anomaly in the $1^{\text {st }}$ quarter (age-groups 2-4) and temperature in the intermediate water layer in May/June as independent variables (a); realised egg production by sprat in Sub-division 26 versus predicted by a multiple linear regression model using spawning stock biomass, growth anomaly (increase in weight at age 2-4 from $3^{\text {rd }}$ to $2^{\text {nd }}$ quarter) and temperature in the intermediate water in May/June as independent variables (b).

perature $(\mathrm{p}=0.021)$ and weight at age anomaly $(\mathrm{p}$ $=0.053)$. Also, $69 \%$ was explained by SSB $(\mathrm{p}<$ $0.001)$, temperature $(\mathrm{p}=0.013)$ and growth anomaly $(\mathrm{p}=0.018)$. The Durbin-Watson statistics did not indicate serial correlation in residuals, and the intercepts in both statistical models were insignificant. For Sub-division 28, weight at age prior to 1985 was assumed to be invariate with time and consequently corresponding tests could be conducted with a shorter time series only. No significant relations to temperature and condition proxies were obtained in this case. 
The ratio of 0-group recruitment to larval abundance was used as a measure of survival to the juvenile stage. This index appeared to be related neither to temperature (intermediate water at spawning time) and oxygen (average oxygen concentration in and below the halocline) in a biologically sensitive way nor with prey availability for sprat larvae (Acartia spp. nauplii and copepodids). In Sub-division 28, a significant negative linear relationship was identified between this index and wind speed anomaly in May/June $\left(r^{2}=-0.26\right)$, whereas in Sub-division 26 $\left(\mathrm{r}^{2}<-0.01\right)$ a high scatter in survival occurred at intermediate wind speed, suggesting rather a parabolic than a linear function. In contrast, multiple lin-

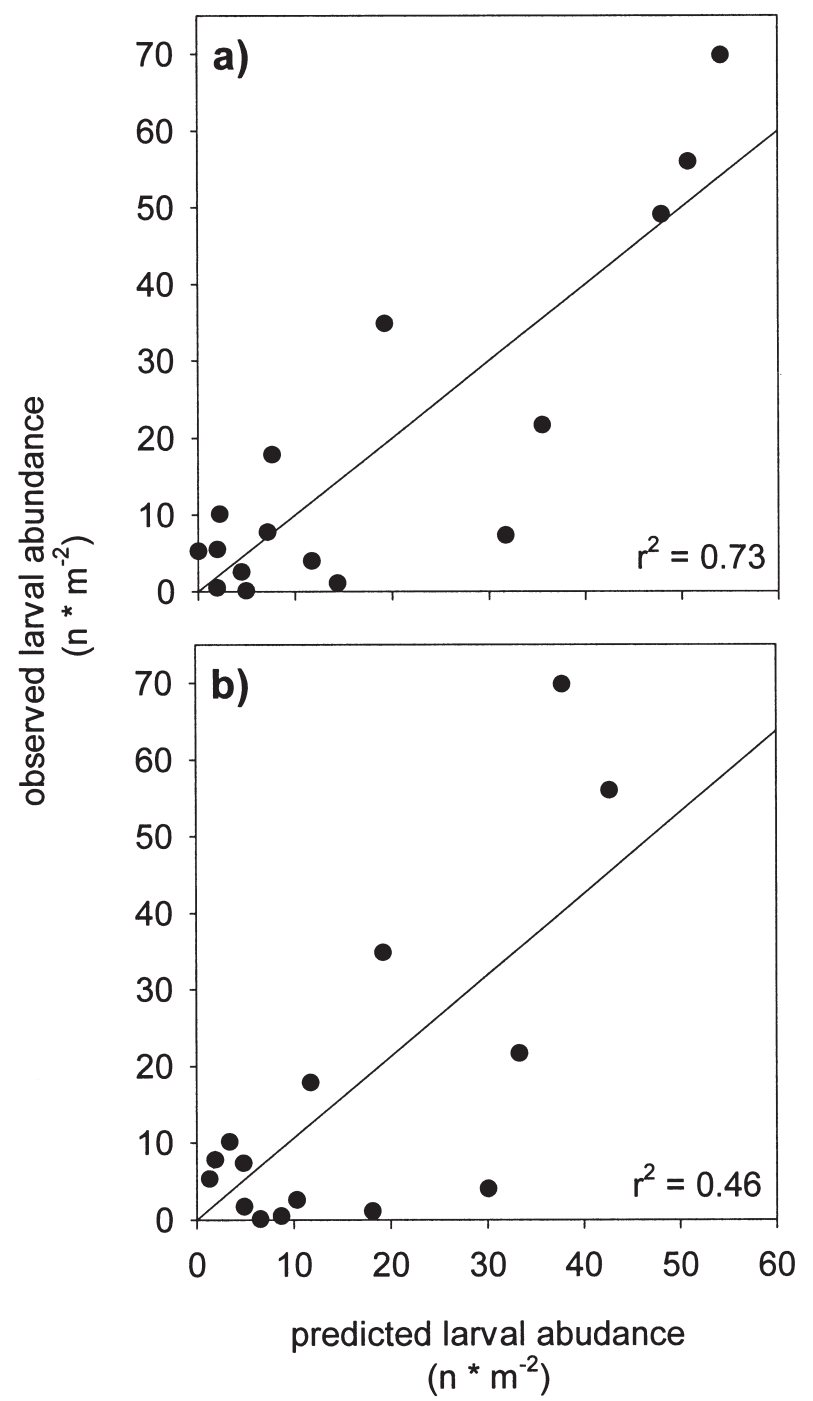

FIG. 7. - Larval abundance of sprat in Sub-division 26 from ichthyoplankton surveys versus predicted by a multiple linear regression model utilising daily egg production of stage III and wind-speed anomaly in May/June as independent variables. ear regressions with late egg stage production values and wind speed anomalies in May/June as independent variables explained 73 and $46 \%$ of the variance in larval abundance in Sub-divisions 26 and 28, respectively (Fig. 7). Wind speed had a statistically significant impact in both areas (Sub-division 26: $\mathrm{p}=$ 0.011 and 28: $\mathrm{p}=0.006$ ). The larval transport index developed for Sub-division 25, on the other hand, did not show a significant effect on larval abundance in Sub-divisions $26(p=0.242)$ or $28(p=0.491)$. Thus, from the available data a significant impact of wind driven transport on larval abundance was not obvious, but the wind speed obviously had an effect on survival from the late egg to the larval stage.

Stepwise multiple linear regression of year class strength on larval abundance and the above-mentioned physical variables revealed a significant effect only for temperature in Sub-division 26 (larval abundance: $\mathrm{p}=0.065$, temperature: $\mathrm{p}=0.028$ ) The explained variance in 0-group recruitment was rather limited (31\%), with the observed recruitment in 1994 being largely underestimated by the model (Fig. 8). Adding further prey availability of Acartia spp. or Temora longicornis or all copepod juvenile life stages in May/June or July/August as a variable did not enhance the statistical model. Also, incorporation of the weight anomaly of 0-group sprat did not increase the explained variance.

In Sub-division 28, a multiple linear regression with larval abundance and temperature as indepen-

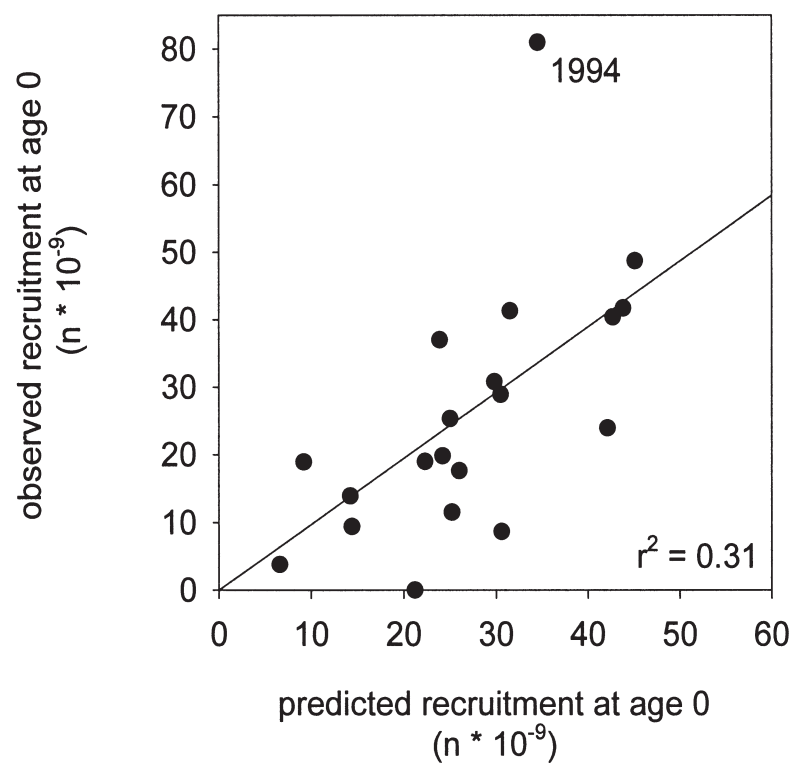

FIG. 8. - Sprat recruitment at age 0 in Sub-division 26 determined by MSVPA versus predicted by a multiple linear regression model utilising larval abundance and temperature in the intermediate water in May/June as independent variables. 

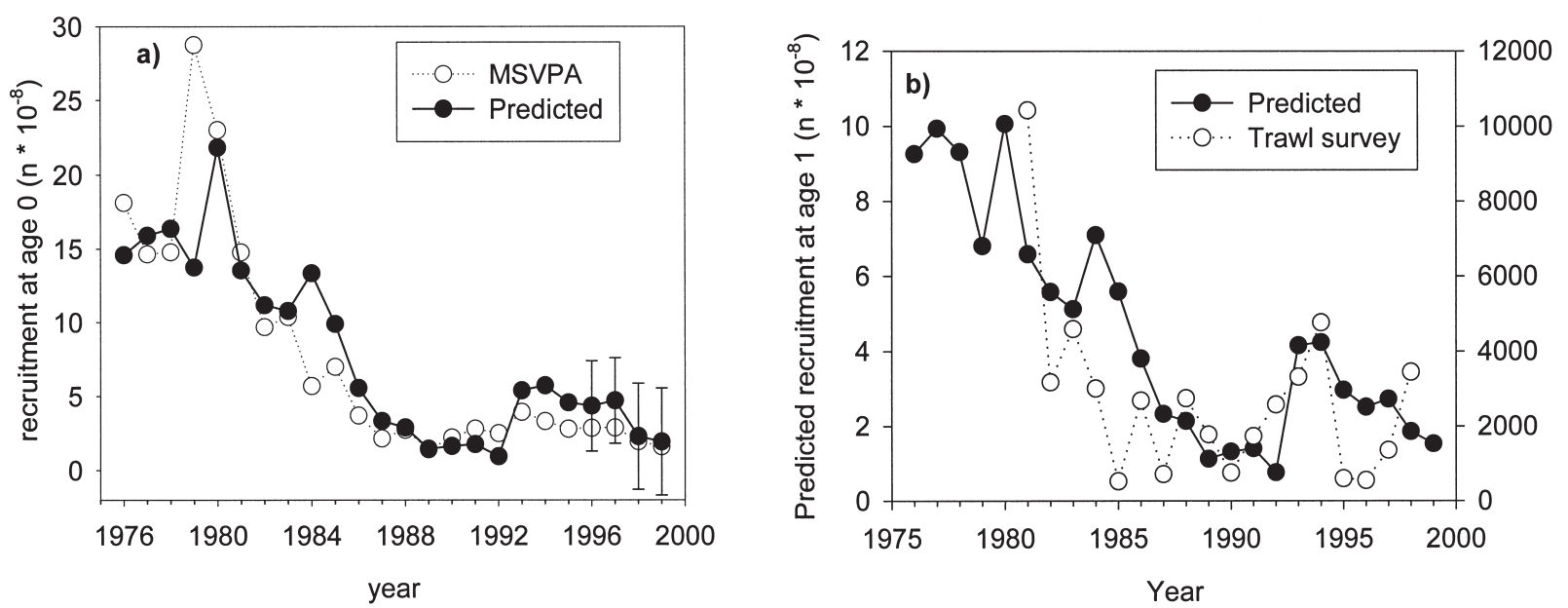

FIG. 9. - Cod recruitment at age 0 in Sub-division 25, 26 and 28 combined (from MSVPA) and predicted by a multiple linear regression model; parameter estimated from data series 1976-1995 and recruitment predicted for 1996-1999 with 95\% confidence limits of the predicted means (a); cod recruitment at age 1 in Sub-divisions 25, 26 and 28 from $1^{\text {st }}$ quarter bottom trawl survey (scaled arithmetic

mean catch rates) and predicted by above multiple linear regression model and applied predicted 0-group predation mortalities (b).

TABLE 6. - Stock-recruitment relationships for sprat (age-group 0 in numbers, SSB in t) in different Sub-divisions with incorporated variables identified to affect critical life stages. The table presents parameter estimates and their significance levels, $\mathrm{r}^{2}$-values and Durbin Watson (DW) statistics indicating serial correlation in the residuals if significant $(*=$ significant at $5 \%$ level).

\begin{tabular}{|c|c|c|c|c|c|c|c|}
\hline Dependent variable & Sub-division & Time series & Independent variables & Parameter estimates & $\mathrm{p}$ & $\mathrm{r}^{2}$ & DW statistics \\
\hline $\begin{array}{l}\text { recruitment at age } 0 \\
\text { MSVPA }\end{array}$ & 26 & $1977-96$ & $\begin{array}{c}\text { SSB } \\
\text { temperature in intermediate water } \\
\text { intercept }\end{array}$ & $\begin{array}{c}61219 \\
1.0505 * 10^{10} \\
-2.2977 * 10^{10}\end{array}$ & $\begin{array}{l}0.014 \\
0.018 \\
0.146\end{array}$ & 0.42 & 2.07 \\
\hline $\begin{array}{l}\text { recruitment at age } 0 \\
\text { MSVPA }\end{array}$ & 26 & $1979-96$ & $\begin{array}{c}\text { SSB } \\
\text { growth anomaly } 3^{\text {rd }} \text { to } 2^{\text {nd }} \text { quarter } \\
\text { intercept }\end{array}$ & $\begin{array}{c}57632 \\
5.6287 * 10^{7} \\
1.5198 * 10^{10}\end{array}$ & $\begin{array}{l}0.030 \\
0.045 \\
0.037\end{array}$ & 0.38 & 1.87 \\
\hline $\begin{array}{l}\text { recruitment at age } 0 \\
\text { MSVPA }\end{array}$ & 26 & $1977-96$ & $\begin{array}{l}\text { SSB } \\
\text { temperature in intermediate water } \\
\text { growth anomaly } 3^{\text {rd }} \text { to } 2^{\text {nd }} \text { quarter } \\
\text { intercept }\end{array}$ & $\begin{array}{c}58015 \\
7.9327 * 10^{9} \\
4.3814 * 10^{7} \\
-1.2862 * 10^{10}\end{array}$ & $\begin{array}{l}0.031 \\
0.087 \\
0.087 \\
0.446\end{array}$ & 0.47 & 2.04 \\
\hline $\begin{array}{l}\text { recruitment at age } 0 \\
\text { hydroacoustic survey }\end{array}$ & 26 & $1981-96$ & $\begin{array}{l}\text { SSB } \\
\text { temperature in intermediate water } \\
\text { intercept }\end{array}$ & $\begin{array}{c}41557 \\
5.3867 * 10^{9} \\
-2.0634 * 10^{10}\end{array}$ & $\begin{array}{l}0.007 \\
0.039 \\
0.043\end{array}$ & 0.49 & 2.62 \\
\hline $\begin{array}{l}\text { recruitment at age } 0 \\
\text { MSVPA }\end{array}$ & 25 & $1977-96$ & $\begin{array}{l}\text { SSB } \\
\text { temperature in intermediate water } \\
\text { intercept }\end{array}$ & $\begin{array}{c}62234 \\
5.9304 * 10^{9} \\
-4.3085 * 10^{9}\end{array}$ & $\begin{array}{l}0.014 \\
0.052 \\
0.680\end{array}$ & 0.45 & 1.93 \\
\hline $\begin{array}{l}\text { recruitment at age } 0 \\
\text { hydroacoustic survey }\end{array}$ & 25 & $1981-96$ & $\begin{array}{l}\text { SSB } \\
\text { temperature in intermediate water } \\
\text { intercept }\end{array}$ & $\begin{array}{c}7469 \\
1.700 * 10^{8} \\
-1.1195 * 10^{9}\end{array}$ & $\begin{array}{l}0.038 \\
0.646 \\
0.477\end{array}$ & 0.22 & 2.23 \\
\hline $\begin{array}{l}\text { recruitment at age } 0 \\
\text { MSVPA }\end{array}$ & 28 & $1977-96$ & $\begin{array}{l}\text { SSB } \\
\text { temperature in intermediate water } \\
\text { intercept }\end{array}$ & $\begin{array}{c}26514 \\
5.2995 * 10^{9} \\
-1.1635^{*} 10^{10}\end{array}$ & $\begin{array}{l}0.166 \\
0.154 \\
0.428\end{array}$ & 0.12 & 2.37 \\
\hline $\begin{array}{l}\text { recruitment at age } 0 \\
\text { hydroacoustic survey }\end{array}$ & 28 & $1981-96$ & $\begin{array}{c}\text { SSB } \\
\text { temperature in intermediate water } \\
\text { intercept }\end{array}$ & $\begin{array}{c}26377 \\
4.2940 * 10^{9} \\
-1.7102 * 10^{10}\end{array}$ & $\begin{array}{l}0.006 \\
0.011 \\
0.011\end{array}$ & 0.63 & 2.01 \\
\hline
\end{tabular}

dent variables only explained a small part of the variance in 0 -group recruitment. Here the only significant physical variable was the larval transport index, which together with the larval abundance explained $26 \%$ of the recruitment variability (larval abundance: $\mathrm{p}=0.104$, temperature: $\mathrm{p}=0.032$ ). However, recruitment was negatively related to the transport index, suggesting lower recruitment in sit- 
uations of transport from Sub-division 25 to eastern basins, which appeared to be biologically not sensible. If recruitment from the hydroacoustic survey was utilised in the above multiple regression analyses instead of MSVPA derived estimates, the wind speed anomaly and the transport index were insignificant while the temperature in the intermediate water became significant; the model explained, however, only $27 \%$ of the variance in 0 -group abundance (larval abundance: $p=0.274$, temperature: $p$ $=0.041$ ). Regardless of the method for estimating 0 group recruitment, prey availability or weight anomalies did not explain a significant part of the variance in sprat recruitment in Sub-division 28.

\section{Environmentally sensitive stock-recruitment relationships}

The conducted exploratory analysis on processes affecting critical early life stages of cod confirmed the results of an earlier analysis (Köster et al., 2001b), and additionally revealed new evidence that food availability affects cod larval survival, which was shown only for one Sub-division due to the lack of suitable data. On this basis, a revision of the multiple regression based cod stock-recruitment model established by Köster et al. (2001b) was not indicated. However, we performed a test of the models developed for the different Sub-divisions which included the potential egg production corrected for egg predation, the ORV and the larval transport index for Sub-division 25, while relatively simple models for both other Sub-divisions included the potential egg production and the RV. Based on these area specific models, we predicted cod recruitment for the period 1996-1999 and compared the prediction for the entire Central Baltic with 0-group abundance data from updated MSVPA runs (ICES, 2001a) and 1-group abundance indices from the international bottom trawl survey (STORE, 2000). MSVPA derived and predicted recruitment were in good agreement (Fig. $9 \mathrm{a})$, both indicating a decline in the reproductive success in most recent years. The comparison with the survey index showed considerably more variability (Fig. 9b), with a similar declining trend at the beginning of the time series, low year-class strength at the end of the 1980s and beginning of the 1990s followed by an increase up to year-class 1994. However, in most recent years, there was an opposite trend in the observed and predicted recruitment.
For sprat, the multiple regression analysis revealed that the spawning stock biomass had a significant effect on 0-group recruitment in almost all areas and combinations of variables. Considering either growth anomaly $(\mathrm{p}=0.045)$ or temperature $(\mathrm{p}=0.018)$ in addition led to $38 \%$ or $42 \%$ explained variance in Sub-division 26 respectively, when recruitment estimates were based on MSVPA; both variables added in combination resulted in $47 \%$ explained variance (Table 6). When utilising recruitment estimates from hydroacoustic surveys, the combination of spawning stock and temperature as independent variables explained $49 \%$ of the variance with the temperature effect ( $\mathrm{p}=0.039)$. In Sub-division 25, temperature was the only variable improving stock-recruitment relationships $(p=0.051)$, but the effect was insignificant when recruitment estimates were derived from hydroacoustic surveys $(\mathrm{p}=0.646)$. In Sub-division 28, the opposite occurred: the temperature effect was statistically significant in a hydroacoustic based stock recruitment relationship ( $\mathrm{p}=0.011)$ but not in the MSVPA-based relationship $(p=0.154)$. Other variables, such as wind speed or growth anomaly were insignificant in any other variable/area combination, regardless of whether recruitment from MSVPA or hydroacoustic survey was utilised.

The best recruitment predictions are presented in Figure 10 for Sub-divisions separately and in Figure 11 for the entire Central Baltic. They are based on multiple regression models including SSB and temperature as independent variables in all three areas, and growth anomalies in addition for Subdivision 26. These statistical models were able to predict the general trends in recruitment success fairly well (Fig. 10), but failed to mirror the large fluctuation in the observed recruitment values in most recent years, with a considerable overestimation of recruitment in 1996 and a significant underestimation in 1994 when compared to MSVPA estimates. This was also obvious for the area aggregated model output (Fig. 11a). Similarly the model predicted recruitment too low in 1997 and too high in 1998, both MSVPA derived recruitment estimates being outside the $95 \%$ confidence limit of the predicted means. Comparing the model with independent recruitment estimates from hydroacoustic surveys showed agreement in both time trends (Fig. 11b), but with substantially lower recruitment indices from the survey in 1990 and again in 1996 and 1998, but not in 1994 . 


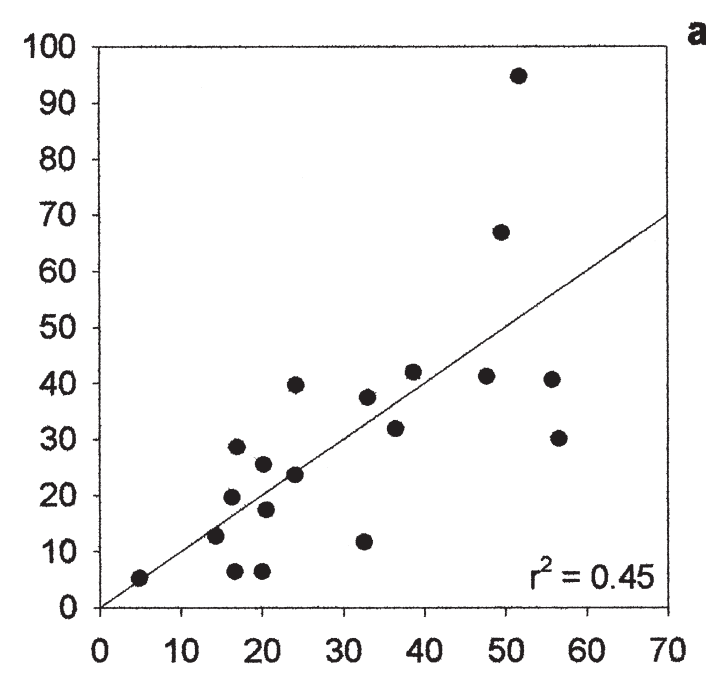

a)
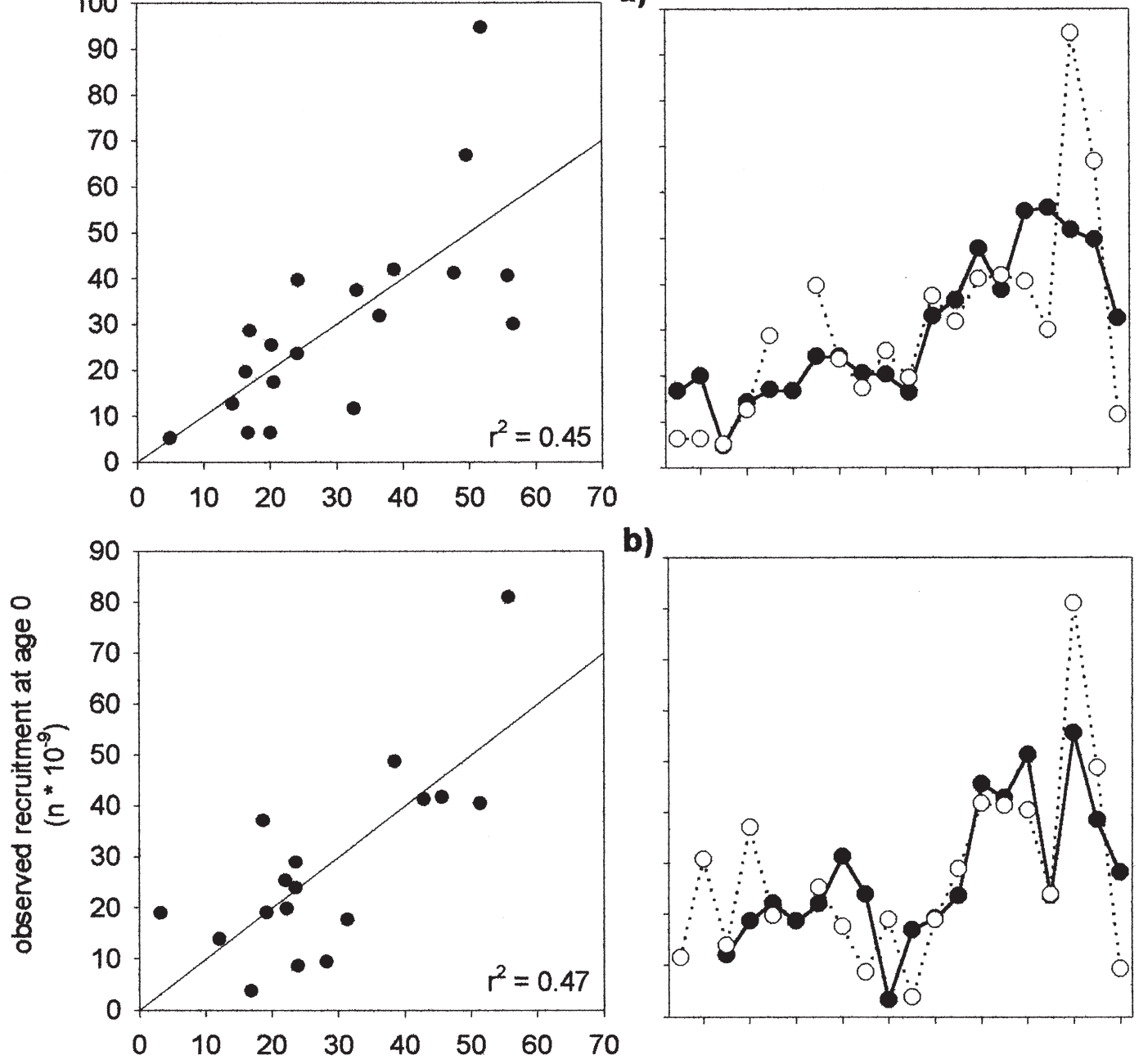

b)
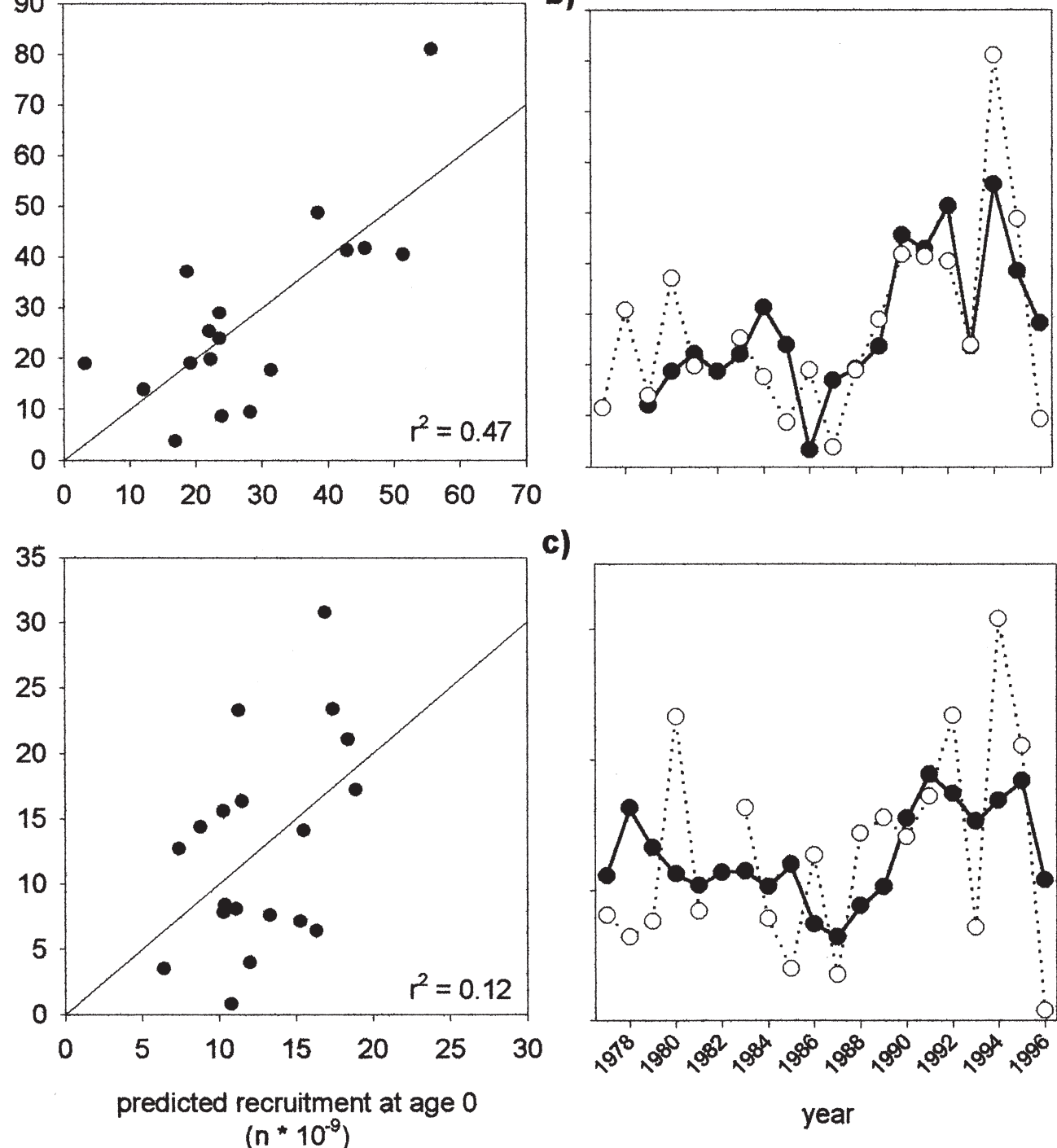

c)

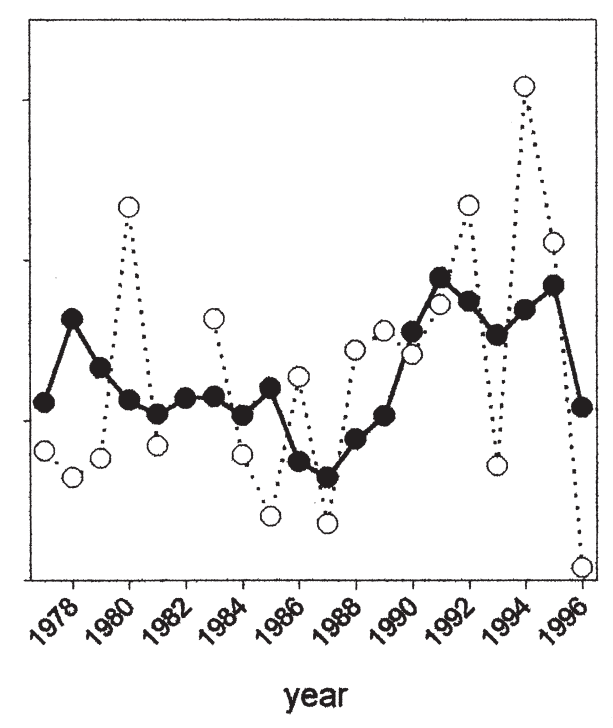

FIG. 10. - Sprat recruitment at age 0 determined by MSVPA and predicted by a multiple linear regression model utilising SSB and temperature in the intermediate water as independent variables for Sub-division 25 (a); sprat recruitment as above adding growth anomaly (available since 1979) as further independent variable for Sub-division 26 (b); sprat recruitment predicted as in Sub-division 25 for Sub-division 28 (c); including time trends of observed (dotted lines and open circles) and predicted values (solid lines and circles) for all three statistical models (right panels). 

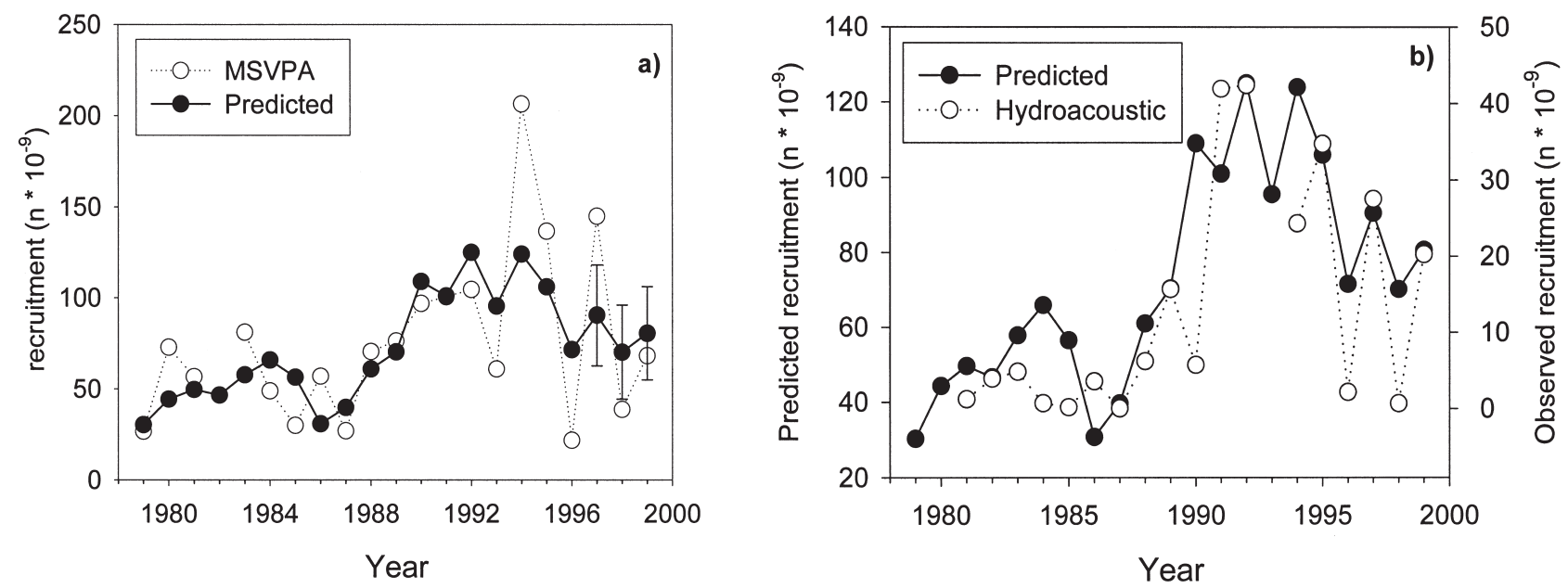

FIG. 11. - Sprat recruitment at age 0 in Sub-divisions 25, 26 and 28 combined, predicted by multiple linear regression models established for separate Sub-divisions and observed recruitment from MSVPA (a) and from autumn hydroacoustic surveys (b).

\section{DISCUSSION}

The present study investigated whether a process-oriented approach based on the results of extensive field, laboratory and modelling studies can be used to develop environmentally sensitive stock-recruitment models, and tried to identify what information might be lacking to make such models as reliable as possible. Our approach attempts to follow the success of a year-class during ontogeny from spawner abundance through the egg and larval to the juvenile stage according to Paulik's (1973) framework for examining the entire life history process, a concept broadly accepted but not really implemented yet (Rothschild, 2000). Investigation of the link between environmental factors, spawning stock features and reproductive success of Baltic cod (e.g. Plikshs et al., 1993; Sparholt, 1996; Jarre-Teichmann et al., 2000) and to a lesser extent also sprat (Grauman and Yula, 1989), have previously been performed by several investigators. However, these studies did not consider the problems inherent in the estimates of egg production based on spawning stock biomass and in the recruitment estimates. Also, they did not attempt to identify specific critical periods within the recruitment process, and apart from Plikshs et al. (1993) did not consider spatial heterogeneity within the Central Baltic. The earlier findings were utilised in the present study to generate the working hypotheses for the process oriented work (for an overview see Schnack and Köster, 1998).

\section{Validation and improvement of stock-recruit- ment relationships}

The comparison of cod SSB and realised egg production clearly demonstrated that spawning stock biomass is no reliable measure of realised egg production, even if yearly or periodically updated maturity ogives are used. It turned out that the female SSB and the predicted potential egg production determined on the basis of the female spawning stock and relative fecundity estimates provide significantly better measures of the realised egg production. They explain 61 and $63 \%$ of the variance in daily production of the youngest egg stage during peak spawning time. The largest deviations between potential and realised egg production, apparent in the most recent year 1996, can be explained by an overestimation of the adult stock size by the MSVPA for Sub-division 25 due to tuning problems (Köster et al., 2001a). Apart from methodological problems, the remaining variability may be related to atresia due to unfavourable environmental conditions during spawning (Kjesbu et al., 1991), variable fertilisation success in relation to salinity changes (Westin and Nissling, 1991) and variation in egg mortality already during the first developmental stage.

For sprat, however, the total spawning stock biomass appeared to be a better measure of realised egg production, indicating that inter-annual variability in maturation processes, age-dependent sex ratios and individual fecundity are of less importance. Although the sex ratio becomes increasingly skewed to female dominance with increasing age in 
sprat (ICES, 2001b), similar to cod (e.g. Tomkiewicz et al., 1997), the observed variability in age-structure of the spawning stock had no major impact on the proportion of females in the stock as the generally dominating age-groups 2 and 3 have rather balanced sex ratios. Variation in sexual maturity of age-group 1 (ICES, 2001b) in combination with high fluctuations in the abundance of this agegroup (Köster et al., 2001a) will, however, result in deviations in SSB estimates derived from yearly maturity ogives as compared to constant standard assessment ogives for individual years. It has been shown that the relationship between SSB and potential egg production of sprat can be improved substantially by incorporating ambient temperature in the intermediate water during spawning time and growth anomaly from the $3^{\text {rd }}$ to the $2^{\text {nd }}$ quarter in a multiple linear regression. The effect of temperature on realised egg production may be due to several reasons: i) low winter temperatures may affect the nutritional condition and growth of sprat (positive relationships between May/June temperature and the growth/nutrition proxies are indicated, but are not statistically significant), ii) low temperature in pre-spawning periods may reduce the batch fecundity as well as the batch number (Petrowa, 1960), and thus the total seasonal egg production, and iii) low temperatures before and during the spawning season may cause a delay in the onset and the peak of spawning activity (e.g. Elwertowski, 1960; Grimm and Herra, 1984). This effect has not been corrected for in the present time series of egg production. The largest deviations between SSB as a measure of egg production and realised egg production occurred in 1996. In this year, specifically low winter temperatures at the surface $(0-50 \mathrm{~m})$ were not fully represented by the May/June temperatures in the intermediate water considered in the model. This may underline the importance of the pre-spawning period for the above mentioned processes.

MSVPA derived cod recruitment at age 1 and 2 compared in general fairly well to trawl survey indices, especially in Sub-divisions 26 and 28. However, the residuals of the linear regression showed a significant auto-correlation over time and the very high year-class strength 1979 estimated by the MSVPA was not confirmed by the trawl surveys. In contrast, most recent year-class estimates from MSVPA fitted well to the surveys indices, which for age-group 2 may be explained by the fact that the survey abundance was been to tune the MSVPA.
MSVPA derived sprat recruitment at age 0 and 1 was highly correlated to corresponding abundance estimates from international hydroacoustic surveys. An exception was the strength of the 1982 year-class in Sub-divisions 26 and 28 being substantially higher in the MSVPA than indicated by the surveys. A similar tendency was obvious from a comparison with an independent sprat recruitment index from the Polish young fish survey in Sub-division 26. Thus, it was concluded that the 1982 recruitment was substantially overestimated by the MSVPA and was consequently removed from the further exploratory analysis.

\section{Identification of critical early life stages}

Difference in the covariance of abundance estimates for successive developmental stages indicated that critical periods for cod recruitment in the Baltic are mainly passed from the egg to the larval stage. The importance of hydrographic conditions within and below the halocline for cod egg survival is well known (e.g. Nissling, 1994; Wieland et al., 1994; MacKenzie et al., 1996), while a poor correlation between late egg stage production and larval abundance has been reported only recently (Köster et al., 2001b). However, Plikshs et al. (1993) pointed out that egg survival is correlated to the reproductive volume but not to year-class strength, indicating that unidentified processes acting on other life stages are important as well. Egg quality characteristics (Petersen et al., 1997; Nissling et al., 1998), low but not lethal oxygen concentrations during egg incubation (Rohlf, 1999), food supply during initial feeding (Plikshs et al., 1993) and transport to favourable nursery areas (Hinrichsen et al., 2001) have been suggested as additional variables with substantial impact on the larval and early juvenile survival. The close correlation between larval abundance and 0-group recruitment suggested, however, that a major part of the remaining variability in reproductive success is already introduced in the egg and early larval stage.

Recruitment at age 0 and 1 determined by MSVPA was very closely related. Increased variability at the beginning of the 1980 s, i.e. a time period with the highest intensity of cannibalism (Köster et al., 2001a). This may indicate that cannibalism is usually of minor importance for the recruitment success of Baltic cod. However, the limited variability in cannibalism rates was to a certain extent artificially created by the estimation procedure imple- 
mented in the MSVPA, which uses constant suitability coefficients over the whole time series, regardless of the size and distribution of the adult and juvenile stock (Neuenfeldt and Köster, 2000).

For sprat, studies on processes affecting the reproductive success in the Baltic are scarce compared to cod. The strong positive linear relationships between production values of early and late egg stages as well as between the late egg stage and larval abundance were unexpected. Given the higher buoyancy of sprat eggs compared to cod (e.g. Wieland and Zuzarte, 1991), a considerable impact of low temperature on egg survival could be expected. Thompson et al. (1981) demonstrated that sprat egg survival decreases at temperatures below $6^{\circ} \mathrm{C}$, which is seldom reached in intermediate water layers of the Baltic. Furthermore, it could be expected that egg predation by clupeids is dependent on the vertical overlap between eggs and predators forced by salinity and oxygen concentrations (Köster and Möllmann, 2000b); this should result in additional variability of egg survival. However, in the given range of variation both temperature and predatorprey overlap seem to have only a limited regulatory impact on egg survival.

The larval stage has earlier been identified as critical for sprat recruitment (Grauman and Yula, 1989; Kalejs and Ojaveer, 1989), suggesting that food supply could be a major impact factor, with temperature being a co-variate, as meso-zooplankton production depends on the temperature conditions, especially in spring (e.g. Möllmann et al., 2000). However, the close relation identified in the present study between the production of the late egg stage and larval abundance in Sub-division 26 suggests that food supply may not vary to a large extent for first feeding larvae in this area, but may do so in Sub-division 28 where a large portion of the variance in larval abundance remains unexplained (77\%). However, it was possible to improve the relationship in both areas considerably by including the wind speed anomaly as an additional variable. The significant positive impact of wind speed may in principal be caused by a wind induced drift of larvae from the Bornholm Basin into the eastern Baltic basins (Grauman, 1976). However, the sprat larval transport index specifically designed to test this hypothesis did not confirm a significant transport. Thus, other processes like enhanced prey encounter rates at increased turbulence may be involved. The present results also did not confirm the hypothesis that high wind stress has a negative effect on egg survival in surface layers (Gauman, 1965). It should be noted, however, that in this analysis only the main spawning period in May/June was considered, in which typically a deeper distribution of sprat eggs is encountered (Wieland and Zuzarte, 1991).

\section{Processes affecting critical early life stages}

The exploratory regression analysis confirmed a significant impact of oxygen and predation on cod egg survival for Sub-division 25. However, these regressions were not specifically convincing. Most observed egg survival rates vary within a certain range, rather independently of the oxygen related survival factor (OES) and the predation index. There were three years $(1976,1978,1994)$ in which the egg survival rates ranged at an obviously higher level. These years were in fact characterised by favourable oxygen supply and low predation rate, but under the same conditions low survival rates were also obtained. By including the information on oxygen and predation in the recruitment model, the potential for a high egg survival is considered but some causal relation is still missing, so estimates for individual years remain uncertain though trends may be represented reasonably well.

The average annual abundance values for cod larvae were to some extent related to the potential egg production, and a part of the remaining variance could be explained by an impact of oxygen on the survival from spawning to the larval stage. Both regressions were statistically significant, but explained only a very limited part of the observed variance in larval abundance. The high residual variance may be due to some additional major impact factor affecting survival during the larval phase or part of it, but it may also be due to sampling problems leading to high variation or bias in larval abundance estimates. As in the most recent years of the time series a delay in cod spawning occurred (Wieland et al., 2000), this may have caused a mismatch in the timing of the plankton surveys and the occurrence of peak larval abundance, and thus may have led to an underestimation of larval abundance (Köster et al., 2001b).

Behavioural studies of cod larvae demonstrated that low oxygen concentration has an impact on larval mortality (Nissling, 1994) and that egg incubation at low oxygen concentration also has an affect on larval activity (Rohlf, 1999). Furthermore, these experiments revealed that vertical migration into 
upper water layers is not started before day 4 after hatch. Hence, a significant impact of the environment within and below the halocline on larval survival can be expected. Due to differences in buoyancy and in the minimum lethal oxygen concentrations in the egg and larval stage (Rohlf, 1999), it appears to be unlikely that the OES is a suitable measure of oxygen related survival probability of larvae. In fact, the ORV performed better in the exploratory analysis and was therefore included in the final model configuration in Sub-division 25.

In the more eastern spawning areas, variability in larval abundance was more easily explained as a highly significant impact of the hydrography is obvious (Köster et al., 2001b). This result was expected as the environmental conditions were less favourable for successful cod egg survival in these areas compared to the Bornholm Basin (MacKenzie et al., 2000). However, a large reproductive volume does not necessarily result in high survival of early life stages. In 1994, an extremely large reproductive volume was encountered in the Gotland Basin due to an inflow into this basin. This inflow displaced the anoxic bottom water upwards (Plikshs et al., 1999), resulting in an intermediate layer with insufficient oxygen concentration but densities sufficient to keep cod eggs floating, and hence creating conditions detrimental to the development of cod eggs. Situations like these clearly demonstrate the potential for index improvement through the development of models for predicting the vertical distribution of cod eggs in all spawning areas relative to oxygen conditions.

One additional factor to be considered for larval survival may be the food supply. Information on the abundance of zooplankton, suitable as prey for cod larvae and early juveniles, has been reviewed by MacKenzie et al. (1996), suggesting that the Central Baltic provides at least similar if not better feeding conditions compared to other spawning areas. Also, from a detailed study based on extensive vertically resolving sampling of zooplankton in different areas of the Central Baltic at various times of the year, Krajewska-Soltys and Linkowski (1994) concluded that the abundance of nauplii and copepodites should be sufficient to ensure that starvation is not a major source of larval and juvenile cod mortality. However, our preliminary test on the impact of the supply of nauplii as suitable prey for first feeding cod larvae (Zuzarte et al., 1996) revealed a significant influence on the apparent survival from egg to larval stage in Sub-division 26. Multiple linear regression including food abundance and reproduc- tive volume (RV) as independent variables explained the variance in larval abundance reasonably well (65\%). Zooplankton data were not available for the period 1992 to 1995. Thus, most of the years in which larval surveys were potentially affected by the shift in spawning time (see above) were excluded from this analysis.

For sprat survival from the larval to the 0-group stage, the exploratory analysis identified the temperature in the intermediate water as the only biologically sensible factor with a marked influence. Neither physical/chemical variables such as the oxygen condition in deep water layers, wind speed anomaly and larval transport index nor biological variables such as food availability or 0-group weight anomaly explained a significant part of the variance encountered in 0-group recruitment. This may lead to the question of the reliability of larval abundance and 0group recruitment data series used in the analysis. As the late egg stage production was significantly related to larval abundance, with a significant improvement when incorporating the wind speed anomaly, it appears to be unlikely that the larval data are grossly erroneous. Using larval abundance data averaged from May to July instead of May to June did not improve the relationship between sprat larval abundance and 0-group recruitment either. Thus, the exclusion of late born cohorts from the analysis did not explain the deviation in abundance estimates between the two life stages. Similarly, significant relationships between MSVPA based recruitment and hydroacoustic survey abundance estimates indicated an acceptable quality of the data series we used in this analysis.

The impact of winter and spring temperature on sprat larval abundance has been described earlier by Grauman and Yula (1989). They identified the solar activity and the spawning stock biomass (as a measure of egg production) as additional significant factors regulating larval abundance. Other variables such as deep water temperature, salinity and oxygen concentration had an effect of intermediate strength on larval abundance. Similar to our results, the availability of nauplii in May did not explain any major portion of the variability (Grauman and Yula, 1989). The impact of temperature on larval abundance was nevertheless explained by a temperature related development of the Temora longicornis population as a thermophil prey species for sprat larvae (Grauman et al., 1986; Kalejs and Ojaveer, 1989).

Also, there was no indication that low weight at age of survivors is coupled to high larval or early 
juvenile mortality, which could be caused by a sizedependent predation of adult herring reported by Patokina and Feldman (1998). It should, however, be noted that the weight anomaly is significantly correlated with the juvenile Acartia spp. abundance in May/June, but not with temperature in the intermediate water.

\section{Applicability of recruitment models}

In Sub-division 25, a significant linear relationship between cod larval abundance and recruitment at age 0 has been described (Köster et al., 2001b), which could not be enhanced by the inclusion of any additional variable. Thus, the simple model appears to be applicable for predicting recruitment. The corresponding relationship in Sub-division 26 was also statistically significant, but the fit of the model was less satisfactory, while for Sub-division 28 no significant relationship could be established. Recruitment success occurred in the latter area in a series of years despite an absolute lack of larvae in the plankton. The occurrence of recruitment estimated by the MSVPA was also confirmed by bottom trawl surveys catching age-group 1 cod. Thus, the lack of larvae indicates either i) a problem in sampling efficiency of the gear at low larval abundance, or ii) a transport of larvae and pelagic 0group out of the Bornholm area into the more eastern Baltic basins. The latter hypothesis is supported by hydrodynamic modelling (Hinrichsen et al., 2001), comparison of trawl survey results and MSVPA output (Köster et al., 2001a), and also by the fact that the parameter estimate for the larval transport index in the recruitment model is negative in Sub-division 25 (Köster et al., 2001b).

The close linear relation between 0 - and 1 group recruitment of cod as well as sprat is to a certain extent artificially created by the estimation procedure implemented in the MSVPA (see above), considering only predation by cod as an additional cause of natural mortality. In fact, on inspecting the cod year-class strength at age 1 and 2 , as derived from the international bottom trawl survey, it appeared that regressions were significant only for Sub-division 26 and 28, but not for Sub-division 25, which was the only area allowing regular reproductive success. For sprat, a regression of 1-group on 0 -group estimates, derived from the international hydroacoustic survey, was significant in Sub-division 25 but not in the other two areas. Even assuming that survey estimates are noisy, especially for pre-recruits not targeted by the survey, this considerably decoupled variation in the abundance estimates of 1 and 2-group cod and 0 - and 1-group sprat may indicate that survival during the first years of life is not only dependent on cod predation, but that other processes also may modify recruitment success substantially.

The recruitment models established here explain a considerable part of the variability encountered in survival to the juvenile stage with a considerably better performance for cod than for sprat. Sprat exhibited high recruitment fluctuations in the most recent years, which the established recruitment model was not able to predict. Remaining variability may be due to a number of processes not included in the present analyses such as egg fertilisation (e.g. Westin and Nissling, 1991) and the influence of parental characteristics (age/size structure, condition) on egg and larval characteristics (buoyancy, survival probability, e.g. Marshall et al., 1998; Trippel, 1998; Vallin and Nissling, 2000), but also uncertainties in the way variables are assumed to represent processes of interest (e.g. reproductive volume effect on cod egg survival, temperature effect on sprat larval survival). Results on these topics have recently become available (e.g. MacKenzie et al., 1998; Nissling et al., 1998; Vallin and Nissling, 2000), and potentially they can be incorporated into new generations of recruitment models (Vallin et al., 1999).

Apart from this potential for improvements, major difficulties in establishing environmentally sensitive stock-recruitment models are i) to incorporate various factors affecting different early life stages (Paulik, 1973) in one linear model relating egg production to subsequent recruitment, and ii) to resolve the potential non-linearity and interdependent effects of different factors on subsequent early life stages. The first problem has been described in detail before (Rothschild, 1986; Ulltang, 1996). Bailey et al. (1996) and Campana et al. (1989) considered it explicitly when constructing survival curves of walleye pollock as well as Nova Scotia cod and haddock cohorts relative to their physical and biological environment. For the Baltic, however, this type of approach has not yet been conducted.

Despite the remaining shortcomings and uncertainties also with respect to the second problem, the stock-recruitment models presented for cod may be utilised for improving short-term recruitment predictions. They could be based on: i) most recent female spawning stock biomass and relative fecun- 
dity estimates (Kraus et al., 2000), ii) hydrographic conditions during spawning periods and at spawning sites, which would enable prediction of the egg and larval survival in relation to ambient oxygen concentrations and larval transport from spawning areas, and iii) predator population sizes as well as spatial overlap between predator/prey, both forced by hydrographic processes. For sprat, the presented analysis should be taken as a first step resolving towards key variables regulating recruitment success, and generating new work hypotheses to be tested in specifically designed process studies and to be validated by subsequent analysis of further extended long-term data bases.

\section{ACKNOWLEDGEMENTS}

This study was carried out within the frame of the EU-projects SAP (FAIR 97 3805) and Baltic STORE (FAIR-98-3959), using process-oriented results and databases built up within the former EUprojects Baltic CORE (AIR-94-1226) and BASYS (MAS3-96-0058). All participants of the projects have contributed their experience, knowledge and results to the present study, which was a prerequisite for this analysis and is thus gratefully acknowledged here.

\section{REFERENCES}

Alekseeva, E.I., M.M. Baranova, M.A., Dmitrieva and E.F. Ryazantseva. - 1997. Ovaries maturation, batch eggs forming, batch fecundity and distribution during sex cycle of Baltic sprat Sprattus sprattus Balticus. C.M. 1997/U:02.

Bagge, O., and F. Thurow. - 1993. The Baltic cod stock: Fluctuations and possible causes. ICES Mar. Sci. Symp., 198: 254-268.

Bagge, O., F. Thurow, E. Steffensen and J. Bay. - 1994. The Baltic cod. Dana, 10: 1-28.

Bailey, K.M., R.D. Brodeur and A.B. Hollowed. - 1996. Cohort survival patterns of walleye pollock Theragra calcogramma, in Shelikof Strait, Alaska: a critical factor analysis. Fish. Oceanogr., 5(Suppl. 1): 179-188.

Begg, G.A. and G. Marteinsdottir. - 2000. Spawning origins of pelagic juvenile cod Gadus morhua inferred from spatially explicit age distributions: potential influences on year-class strength and recruitment. Mar. Ecol. Progr. Ser., 202: 193-217.

Beverton, R.J.H. and T.C. Iles. - 1992. Mortality rates of 0-group plaice (Platessa platessa L.), dab (Limanda limanda L.) and turbot (Scophthalmus maximus L.) in European waters. III. Density dependence of mortality rates of 0-group plaice and some demographic implications. Neth. J. Sea Res., 29: 61-79.

Bleil, M., and R. Oeberst. - 1996. The fecundity of cod in ICES Sub-divisions 22, 24 and 25 in the years 1992 to 1995 (preliminary results). ICES C.M. 1996/J:8.

Campana, S.F., K.T. Frank, P.C.F. Hurley, P.A. Koeller, F.H. Page and P.C. Smith. - 1989. Survival and abundance of young Atlantic cod (Gadus morhua) and haddock (Melanogrammus aeglefinus) as indicators of year class strength. Can. J. Fish. Aquat. Sci., 46(Suppl. 1): 171-182.

CORE - 1998. Mechanisms influencing long term trend in repro- ductive success and recruitment of Baltic cod: Implications for fisheries management. Final Report to the EU Commission, AIR 941226

Elwertowski, J. - 1960. Biologische Grundlagen der Sprottenfischerei in der östlichen und mittleren Ostsee. Fisch. Forsch. 3(4): 1-19.

Grauman, G.B. - 1965: Some data on the reproduction of sprat in the southern part of the Baltic Sea in the period 1958-1964. ICES C.M. 1965/Baltic-Belt Seas Committee Paper, No. 121.

Grauman, G.B. - 1976. On the distribution and passive migration of Baltic sprat eggs and larvae in Bornholm-Slupsk spawning ground. ICES C.M. 1976/P:8.

Grauman, G.B., and K. Krenkel. - 1986. Investigations about the dynamic of spawning processes of the Baltic sprat in 1984 ICES C.M. 1986/J:17.

Grauman, G.B., and E. Yula. - 1989. The importance of abiotic and biotic factors in early ontogenesis of cod and sprat. Rapp. P.-v. Réun. Cons. Int. Explor. Mer, 190: 207-210.

Grauman, G.B., R.J. Line, and L.L. Sidrevics. - 1986. On the factors determining abundance of Baltic sprat. ICES C.M. 1986/J:8.

Grimm, S.K., and T. Herra. - 1984. Spawning cycles of southern Baltic fishes based on surveys of eggs and larvae. ICES CM 1984/J:30.

Heath, M. and A. Gallego. - 1997. From the biology of the individual to the dynamics of the population: bridging the gap in fish early life studies. J. Fish Biol., 51 (Suppl. A): 1-30.

Herra, T. - 1988. Ichthyoplankton survey in the southern Baltic in August 1987. ICES C.M. 1988/L:23.

Herra, T., and S.K. Grimm. - 1983. Preliminary results of ichthyoplankton surveys of the southern Baltic Sea in May 1983. ICES C.M. 1983/L:15.

Hinrichsen, H.-H., M.A. St. John, E. Aro, P. Grønkjær and R. Voss. -2000 . Testing the larval drift hypothesis in the Baltic Sea: Retention vs. dispersion due to the influence of the wind driven circulation. ICES J. Mar. Sci., 58: 973-984.

Hutchings, J.A. and R.A. Myers. - 1993. Effect of age on the seasonality of maturation and spawning of Atlantic cod, Gadus morhua, in the Northwest Atlantic. Can. J. Fish. Aquat. Sci., 50: 2468-2474.

ICES. - 1976. Report of the Working Group on Surveys of Fish Eggs and Larvae in the Baltic. ICES C.M. 1976/P:10.

ICES. - 1994. Report of the Planning Group for Hydroacoustic Surveys in the Baltic. ICES C.M. 1994/J:4.

ICES. - 1996. Report of the Baltic Fisheries Assessment Working Group. ICES C.M. 1996/Assess:13.

ICES. - 1997. Report of the Baltic Fisheries Assessment Working Group. ICES C.M. 1997/Assess:12.

ICES. - 1998. Report of the Baltic Fisheries Assessment Working Group. ICES C.M. 1998/ACFM:16.

ICES. - 1999a. Report of the Baltic Fisheries Assessment Working Group. ICES C.M. 1999/ACFM:15.

ICES. - 1999b. Report of the Study Group on Multispecies Model Implementation in the Baltic. ICES C.M. 1999/H:5.

ICES. - 2000. Report of the Baltic Fisheries Assessment Working Group. ICES C.M. 2000/ACFM:14.

ICES. - 2001a. Report of the Study Group on Multispecies Predictions in the Baltic. ICES C.M. 2001/H:5.

ICES. - 2001b. Report of the Study Group on Baltic herring and sprat maturity. ICES 2001/ACFM:24.

Jarre-Teichmann, A., K. Wieland, B.R. MacKenzie, H.-H. Hinrichsen, M. Plikshs and E. Aro. - 2000. Stock-recruitment relationships for cod (Gadus morhua callarias L.) in the central Baltic Sea incorporating environmental variability. Arch. Fish. Mar. Res., 48: 97-123.

Kalejs, M., and E. Ojaveer. - 1989. Long-term fluctuations in environmental conditions and fish stocks in the Baltic. Rapp. P-v Réun. Cons. Int. Explor. Mer, 190: 153-158.

Karasiova, E. - 1999. On the possible relation of the cod peak spawning timing with the environmental conditions in the Gdansk Deep of the Baltic Sea. ICES CM 1999/Y:29.

Kendall, A.W., Schumacher, J.D., and S. Kim. - 1996. Walleye pollock recruitment in Shelikof Strait, Alaska. Fish. Oceanogr., 5(Suppl. 1): 4-18.

Kjesbu, O.S., J. Klungsoyr, H. Kryvi, P.R. Witthames and M. Greer Walker. - 1991: Fecundity, atresia and egg size of captive Atlantic cod (Gadus morhua) in relation to proximate body composition. Can. J. Fish. Aquat. Sci., 48: 2333-2343. 
Köster, F.W., and D. Schnack. - 1994. The role of predation on early life stages of cod in the Baltic. Dana, 10: 179-201.

Köster, F.W., and C. Möllmann. - 2000a. Trophodynamic control by clupeid predators on recruitment success in Baltic cod? ICES J. Mar. Sci., 57: 310-323.

Köster, F.W., and C. Möllmann. - 2000b. Egg cannibalism in Baltic sprat Sprattus sprattus. Mar. Ecol. Progr. Ser., 196: 269-277.

Köster, F.W., C. Möllmann, M.A. St. John, S. Neuenfeldt, M. Plikshs and R. Voss. - 2001a. Developing Baltic cod recruitment models I: Resolving spatial and temporal dynamics of spawning stock and recruitment. Can. J. Fish. Aquat. Sci., 58: 1516-1533.

Köster, F.W., H.H. Hinrichsen, M.A. St. John, D. Schnack, B.R. MacKenzie, J. Tomkiewicz and M. Plikshs. - 2001b. Developing Baltic cod recruitment models II: Incorporation of environmental variability and species interaction. Can. J. Fish. Aquat. Sci., 58: 1535-1557.

Krajewska-Soltys, A. and T.B. Linkowski. - 1994. Densities of potential prey for cod larvae in deep-water basins of the southern Baltic. ICES CM 1994/J:17.

Kraus, G., A. Müller, K. Trella and F.W. Köster. - 2000. Fecundity of Baltic cod: temporal and spatial variation. J. Fish Biol., 56: 1327-1341.

Krenkel, K. 1981: Über das Vorkommen der Eier und Larven von Sprott (Sprattus sprattus) und Dorsch (Gadus morhua) in der Ostsee in den Jahren 1977-1980. Fisch.-Forsch., 19: 31-36.

Lambert, Y. and J.-D. Dutil. - 2000. Energetic consequences of reproduction in Atlantic cod (Gadus morhua) in relation to spawning level of somatic energy reserves. Can. J. Fish. Aquat. Sci., 57: 815-825.

Larkin, P.A. and A.S. Hourston. - 1964. A model for simulation of the population biology of Pacific salmon. J. Fish. Res. Bd Can., 21: $1245-1265$.

Leggett, W.C. and E. DeBlois. - 1994. Recruitment in marine fishes: is it regulated by starvation and predation in the egg and larval stages?. Neth. J. Sea Res., 32: 119-134.

Line, R.J. 1979. Some observations on fecundity and development cycles of the main zooplankton species in the Baltic sea and the Gulf of Riga. In: Fisheries investigations in the basins of the Baltic sea. Riga, Zvaigzne, 14: 3-10 (in Russian).

MacKenzie, B.R., M.A. St. John and K. Wieland. - 1996. Eastern Baltic cod: perspectives from existing data on processes affecting growth and survival of eggs and larvae. Mar. Ecol. Prog. Ser., 134: 265-281.

MacKenzie, B.R., J. Tomkiewicz, F.W. Köster and A. Nissling. 1998. Quantifying and disaggregating the 'spawner' effect: incorporating stock structure, spatial distribution and female influence into estimates of annual population egg production. ICES C.M. 1998/BB:11.

MacKenzie, B.R., H.-H. Hinrichsen, M. Plikshs, K. Wieland and A.S. Zezera. - 2000. Quantifying environmental heterogeneity: habitat size necessary for successful development of cod Gadus morhua eggs in the Baltic Sea. Mar. Ecol. Progr. Ser., 193: 143-156.

Marshall, T.C., O.S. Kjesbu, N.A. Yaragina, P. Solemdal and $\varnothing$ Ulltang. - 1998. Is spawner biomass a sensitive measure of the reproductive and recruitment potential of Northeast Arctic cod. Can. J. Fish. Aquat. Sci., 55: 1766-1783.

Marteinsdottir, G. and A. Steinarsson. - 1998. Maternal influence on the size and viability of Iceland cod Gadus morhua eggs and larvae. J. Fish Biol. 52, 1241-1258.

Marteinsdottir, G., and K. Thorarinsson. - 1998. Improving the stock-recruitment relationship in Icelandic cod (Gadus morhua L.) by including age diversity of spawners. Can. J. Fish. Aquat. Sci., 55: 1372-1377.

Möllmann, C., G. Kornilovs and L. Sidrevics. - 2000. Long-term dynamics of main mesozooplankton species in the central Baltic Sea. J. Plank. Res., 22: 2015-2038.

Müller, A. - 1988. Vertical distribution of ichthyoplankton in the Bornholm Basin. Kieler Meeresforsch. Sonderh., 6: 341-347.

Myers R.A. and N.C. Cadigan. - 1993. Density-dependent juvenile mortality in marine demersal fish. Can. J. Fish. Aquat. Sci., 50: 1576-1590.

Neuenfeldt, S., and F.W. Köster. - 2000. Trophodynamic control on recruitment success in Baltic cod: the influence of cannibalism. ICES J. Mar Sci., 57: 300-309.

Nissling, A. - 1994. Survival of eggs and yolk-sac larvae of Baltic cod (Gadus morhua L.) at low oxygen levels in different salinites. ICES Mar. Sci. Symp., 198: 626-631.
Nissling, A., R. Larsson, L. Vallin and K. Frohlund. - 1998. Assessment of egg and larval viability in cod, Gadus morhua - methods and results from an experimental study. Fish. Res., 38: 169-186.

Ojaveer, E. - 1989. Population structure of pelagic fishes in the Baltic. Rapp. P-v Réun. Cons. Int. Explor. Mer, 190: 17-21.

Ojaveer, E., A. Lumberg, and H. Ojaveer. - 1998. Highlights of zooplankton dynamics in Estonian waters (Baltic Sea). ICES J. Mar. Sci., 55: 748-755.

Parmanne, R., O. Rechlin and B. Sjöstrand. - 1994. Status and future of herring and sprat stocks in the Baltic Sea. Dana, 10: 29-59.

Patokina, F.A. and V.N. Feldman. - 1998. Peculiarities of trophic relations between Baltic herring (Clupea harengus membras L.) and sprat in the south eastern Baltic Sea in 1995-1997. ICES CM 1998/CC:7.

Paulik, G.J. - 1973. Studies of the possible form of the stockrecruitment curve. Rapp. P.-v. Réun. Cons. int. Explor. Mer, 164: $302-315$

Petersen, G.I., J. Gerup, L. Nilsson, J.R. Larsen and R. Schneider. 1997. Body burdens of lipophilic xenobiotics and reproductive success in Baltic cod (Gadus morhua). ICES C.M. 1997/U:10.

Petrowa; E.G. - 1960. Fecundity and maturation of sprat in the Baltic. VNIRO, 42: 99-108.

Polivaiko, A.G. - 1980. Some data on maturation, spawning and fecundity of sprat. Fisch. Forsch., 18: 69-72.

Plikshs, M., M. Kalejs and G. Graumann. - 1993. The influence of environmental conditions and spawning stock size on the yearclass strength of the eastern Baltic cod. ICES C.M. 1993/J:22.

Plikshs, M., H.-H. Hinrichsen, F.W. Köster, J. Tomkiewicz and V. Berzins. - 1999. Baltic cod reproduction in the Gotland Basin: annual variability and possible causes. ICES C.M. 1999/Y:31.

Raid, T. - 1989. The influence of hydrodynamic conditions on the spatial distribution of young fish and their prey organisms. Rapp. P-v Réun. Cons. Int. Explor. Mer, 190: 166-172.

Rohlf, N. - 1999. Aktivität und Vertikalwanderung der Larven des Ostseedorsches (Gadus morhua callarias) während der Dottersackphase. $\mathrm{PhD}$. thesis, University Kiel, Ber. Inst. für Meereskunde, 312, 62pp.

Rothschild, B.J. - 1986. Dynamics of Marine Populations. Harvard University Press, Cambridge, USA.

Rothschild, B.J. - 2000. "Fish stock and recruitment": the past thirty years. ICES J. Mar Sci., 57: 191-201.

Rudstam, L.G., G. Aneer and M. Hildén. - 1994. Top-down control in the pelagic Baltic ecosystem. Dana, 10: 105-129.

Schnack, D. - 1997. Influence of hydrographic gradients and fishery on the biological interaction and balance between sprat and cod stocks in the Baltic Sea. Commented review. ICES CM 1997/S:10.

Schnack, D., and F.W. Köster. - 1998. Baltic Cod Recruitment Project: Summary of results 1994-97. ICES CM 1998/R:21.

Shapiro, L.A. - 1990. Correlation between the quantity and quality of the gonads in the Baltic cod. Can. Transl. Fish. Aquat. Sci., no. 5515 .

Sidrevics, L.L. - 1984. The main peculiarities of zooplankton distribution in the south-eastern, eastern and north-eastern Baltic. Articles on biological productivity of the Baltic Sea, 2: 172-187 (in Russian).

Sparholt, H. - 1996. Causal correlation between recruitment and spawning stock size of central Baltic cod? ICES J. Mar. Sci., 53: 771-779.

Sparholt, H., and J. Tomkiewicz. - 2000. A robust method to compile trawl survey data applied in assessment of Central Baltic cod. Arch. Fish. Mar. Res., 48: 125-151.

St. John, M.A., H. Mosegaard, H.-H. Hinrichsen, P. Grønkjær, F.W. Köster, K. Hüssy and R. Nielsen. - 2000. Baltic Cod: Resolving processes determining spatial and temporal windows of survival. ICES C.M. 2000/N:27.

STORE. - 2000. Environmental and fisheries influences on fish stock recruitment in the Baltic Sea. Consolidated Progress Report 01.01.-31.12.1999 to the EU Commission, FAIR-983959 Part $1 \& 2$

STORE. - 2001. Environmental and fisheries influences on fish stock recruitment in the Baltic Sea. Consolidated Progress Report 01.01.-31.12.2000 to the EU Commission, FAIR-983959 Part $1 \& 2$.

Thompson, B.M., S.P. Milligan and J.H. Nichols. - 1981. The development rates of sprat (Sprattus sprattus L.) eggs over a range of temperatures. ICES C.M. 1981/H:15. 
Tomkiewicz, J., M. Eriksson, T. Baranova, V. Feldman and H. Müller. - 1997. Maturity ogives and sex ratios for Baltic cod: establishment of a database and time series. ICES CM 1997/CC:20.

Trippel, E.A. - 1998. Egg size and viability and seasonal offspring production of young Atlantic cod. Am. Fish. Soc., 127: 339-359.

Trippel, E., O.S. Kjesbu and P. Solemdal. - 1997. Effects of adult age and size structure on reproductive output in marine fishes. In: Chambers, C.R. and Trippel. E.A. (eds.), Early Life History and Recruitment in Fish Populations, pp. 29-62. Chapman and Hall Fish and Fisheries Series, London.

Ulltang, Ø. - 1996. Stock assessment and biological knowledge: can prediction uncertainty be reduced. ICES J. Mar. Sci., 53: 659-675.

Vallin, L., and A. Nissling. - 2000. Maternal effects on egg size and egg buoyancy of Baltic cod, Gadus morhua. Implications for stock structure effects on recruitment. Fish. Res., 49: 21-37.

Vallin, L., A. Nissling and L. Westin. - 1999. Potential factors influencing reproductive success of Baltic cod, Gadus morhua: a review. Ambio, 28: 92-99.

Vuorinen,I., J. Hänninen, M. Viitasalo, U. Helminen and H. Kuosa.
- 1998. Proportion of copepod biomass declines with decreasing salinity in the Baltic Sea. ICES J. Mar. Sci., 55: 767-774.

Westin, L., and A. Nissling. - 1991. Effects of salinity on spermatozoa motility, percentage of fertilized eggs and egg development of Baltic cod Gadus morhua, and implications for cod stock fluctuations in the Baltic. Mar. Biol., 108: 5-9.

Wieland, K. and F. Zuzarte. - 1991. Vertical distribution of cod and sprat eggs and larvae in the Bornholm Basin (Baltic Sea) 19871990. ICES CM 1991/J:37.

Wieland, K., and A. Jarre-Teichmann. - 1997. Prediction of vertical distribution and ambient development temperature of Baltic cod (Gadus morhua L.) eggs. Fish. Oceanogr., 6: 172-187.

Wieland, K., U. Waller and D. Schnack. - 1994. Development of Baltic cod eggs at different levels of temperature and oxygen content. Dana, 10: 163-177.

Wieland, K., A. Jarre-Teichmann and K. Horbowa. - 2000. Changes in the timing of spawning of Baltic cod: possible causes and implications for recruitment. ICES J. Mar. Sci., 57: 452-464.

Zuzarte, F., F.W. Köster, C. Möllmann, R. Voss and P. Grønkjær. 1996. Diet composition of cod larvae in the Bornholm Basin. ICES C.M. 1996/J:19. 